Article

\title{
Employee Satisfaction, Corporate Social Responsibility and Financial Performance
}

\author{
Chu-Hsuan Chang ${ }^{1}$, Hsiou-Wei Lin ${ }^{2}$, Wen-Hsien Tsai ${ }^{3}$, Wei-Liang Wang ${ }^{3}$ and Cheng-Tsu Huang ${ }^{3, *}$ \\ 1 Department of Finance, National Taipei University of Business, Taipei 10026, Taiwan; cchgm101@gmail.com \\ 2 Department of International Business, National Taiwan University, Taipei 10617, Taiwan; plin@ntu.edu.tw \\ 3 Department of Business Administration, National Central University, Jhongli, Taoyuan 32001, Taiwan; \\ whtsai@mgt.ncu.edu.tw (W.-H.T.); williamweiliang7810@gmail.com (W.-L.W.) \\ * Correspondence: chengtsu.huang@gmail.com; Tel.: +886-3-4227151 (ext. \#66178)
}

check for updates

Citation: Chang, C.-H.; Lin, H.-W.;

Tsai, W.-H.; Wang, W.-L.; Huang, C.-T. Employee Satisfaction, Corporate Social Responsibility and Financial Performance. Sustainability 2021, 13, 9996. https://doi.org/10.3390/ su13189996

Academic Editor: Andrea Appolloni

Received: 16 July 2021

Accepted: 31 August 2021

Published: 7 September 2021

Publisher's Note: MDPI stays neutral with regard to jurisdictional claims in published maps and institutional affiliations.

Copyright: (c) 2021 by the authors. Licensee MDPI, Basel, Switzerland. This article is an open access article distributed under the terms and conditions of the Creative Commons Attribution (CC BY) license (https:// creativecommons.org/licenses/by/ $4.0 /)$.

\begin{abstract}
This study explores the extent to which employee turnover, a proxy variable to employee loyalty, helps mediate the relationship between Taiwanese firms' corporate social responsibility (CSR) performance and financial outcome. The results show that a firm's CSR performance is negatively correlated with employee turnover and turnover variability, and moreover, employee turnover is negatively correlated with a firm's financial performance. The result is especially noteworthy for studies regarding Taiwanese companies since quite a few of them are original equipment manufacturers (hereafter also referred to as OEMs), of intermediate goods. For the sample firms, although the contribution of social responsibility appears to have insignificantly direct benefit on financial performance, we document that the extent to which CSR conducts influence on long-term financial outcomes may be moderated and mediated by employee enthusiasm.
\end{abstract}

Keywords: corporate social responsibility; employee turnover; mediation effect

\section{Introduction}

This study applies a mediation model and conducts regression analysis of the companies that received the "Corporate Citizenship Award," which has been presented by CommonWealth Magazine since 2007, as a corporate social responsibility (CSR) indicator. In the 21st century, there has been growing and substantial efforts exerted by the companies on corporate social responsibility issues for either a competitive strategy or out of charity. According to a survey conducted by McKinsey \& Company, more than $90 \%$ of the companies indicate that they incorporate more environmental, social, and governance issues into their core strategies than before. However, there is a debate on whether entrepreneurs pursued CSR between corporate social ethics and corporate financial performance because CSR would seemingly increase the expenses for firms in the short term. Despite that, some studies document a positive correlation between CSR and financial performance, the findings in prior research show somewhat mixed evidence on the relationship between CSR achievements and financial performance [1]. CSR is multifaceted and difficult to measure [2], and because of this, the relationship between CSR achievements and accounting-based financial outcomes remains uncertain [3].

Nevertheless, with the emergence of stakeholder theory, the interests of the stakeholders including employees, customers/consumers, communities, upstream as well as downstream firms, and the government gradually become internalized by the businesses. The increased CSR awareness of firms coincides with a growing attention from the society on the quality of life beyond narrow economic interests, which has accelerated the ethical dimension of business conducts. Consumers increasingly include social and environmental compliances of the businesses in their purchasing decisions. Namely, the effects of such perceived compliances on customer satisfaction and loyalty may reward the sustainable development of the enterprises. Among the corporate environmental compliances, for 
instance, either ecological footprints, emissions, consumption, renewable resources, ecoefficiency, or in combination, may serve as the strategic variables [4]. Individual investors and institutional investors may become more inclined to incorporate the CSR accomplishments of the companies in their investment decisions, and governments around the world are implementing more stringent environmental and social policies. All of the above will directly or indirectly affect the conduct and performance of the companies. Traditional literature on the relationship between CSR and financial performance, nevertheless, fails to consider how the potential mediators for CSR achievements affect financial performance. In contrast with prior literature, this study focuses on the internal environmental factors and examines whether CSR affects financial performance through employee perceptions.

In practice, employee relations management and the role of employees in CSR may also be among the key success issues. For example, Fortune magazine periodically lists the 100 Best Employers in the United States, and companies on the list can retain and recruit employees more easily than those not on the list, thus the former group of firms may enjoy outperforming productivity at a relatively low cost [5]. By engaging itself in CSR activities that may be appreciated by the employees, a company may improve employee morale, employee productivity, and employee satisfaction, leading to better overall corporate performance [6]. Specifically, CSR may be a transmission mediation that influences employees' general impression of their company and affects the relationship between the employees and the company by (a) eliminating concerns about safety and security, (b) providing positive corporate distinctiveness and enhancing social identity, (c) symbolizing a commitment to essential values and engendering a sense of belongingness, and (d) adding and providing a greater sense of purpose at work. These four different channels correspond to four universal psychological needs: security, self-esteem, belongingness, and meaningful existence [7].

Sound CSR performance may result in better financial performance to a company for two reasons, (1) higher stock price as a result of the enhanced market perceptions, and (2) the reactions that add to the firm value of corporate stakeholders as reflected either in earnings achieved through increased revenues, greater customer satisfaction, reduced production costs, higher supplier/employee satisfaction, lower capital costs resulted from optimistic bank or investor attitudes, or in combination. However, the prior literature does not clarify whether and the extent to which certain mediation channels may affect the significance of the impact of CSR on the stakeholders on corporate financial performance. Specifically, for instance, for a company typically engaging itself in a business-to-business (B-to-B) form of transactions, whether its positive voluntary community service activities would add to its employee, supplier or customer satisfaction and therefore its profitability may be an empirical issue. In a business-to-business (B-to-B) form of transactions, it is not unquestionable that the customer firms would always appreciate the suppliers' allocating the resources for their CSR activities. The situation may be that as long as the suppliers have no negative image with respect to CSR, the customers' willingness to place the purchase orders may primarily be influenced by either product conformity, price, on-time delivery, or in combination.

In contrast to Freeman's macroscopic inference, this study uses employee turnover as an indicator of employee response to conduct an empirical study on corporate financial performance. This study conjectures that underinvestment in CSR will lead to a poorer corporate image and lower employee morale, which will worsen the subsequent turnover. Specifically, there are three themes explored in this study: (1) the relationship between the degree of CSR and employee turnover; (2) the relationship between employee turnover and financial performance; and (3) impact of CSR on corporate financial performance through the mediation effect of employee turnover. For the sample firms, despite that the contribution of social responsibility appears to have insignificantly direct benefit on financial performance, we document that the extent to which CSR conducts influence longterm financial outcomes may be moderated and mediated by the employee enthusiasm. 
This study differs from prior ones in that it focuses on CSR's impact on the productivity variable of the labor production factor, which, in turn, connects to corporate financial variables. Extant literature focuses on the relationship between two variables, CSR and financial performance. Intuitively, corporate expenditures on CSR would help increase the firm value. However, mixed results exist regarding whether an investment in CSR would benefit the shareholders. In contrast with prior literature, this study focuses on the role of employee relations, as employee satisfaction affects productivity, internal yields, education and training, quality control and maintenance costs, and R\&D effectiveness. Furthermore, this study suggests a mediation effect of employee turnover between CSR and corporate financial performance while the mediation effects of CSR are parsimoniously discussed in prior literature. Therefore, this study adds to the literature by clarifying the relationship between CSR and financial performance through the mediation model framework. Finally, the implications of this study for research and practice for future studies include a broader investigation of (1) the roles that the (other) potential mediators play on the effectiveness of CSR efforts on enhancing the shareholders' value, and (2) the extent of the best firm-specific practice of CSR.

The next section discusses the backgrounds of CSR and reviews literature, Section 3 develops our hypotheses, Section 4 explains the data sources and the research design, and Section 5 presents the results. Finally, we discuss and conclude our findings in Sections 6 and 7.

\section{Backgrounds of CSR and Literature Review}

\subsection{Implications and Measurement of CSR}

Quite a few scholars have expressed various views on the motivations of CSR. For example, Bowen [8] states that businesses should emphasize the overall impact of their decisions rather than just the safety and profitability of the businesses. In contrast, the neoclassical economists' statements appear to be against the CSR. Specifically, such theories suggest that the responsible firms focus on optimizing their product or service line operations in order to maximize firm profits and thus the shareholders, who are not artificial beings, are able to engage in their desired social activities [9]. After CSR attracted significant attention, although scholars have held both positive and negative views, different theories have been put forward to explain the relationship between operating outcomes and CSR, and the stakeholder theory is one of them. Stakeholder theory is the key to understanding the structure and aspects of the relationship between businesses and society because it helps explain the relationship between various business performance indicators [10]. The stakeholder theory recognizes that stakeholders, e.g., shareholders, employees, customers, competitors, communities, upstream and downstream suppliers, and governments, are the recipients of a company's actions and outcomes and the source of judgments about how well the company is meeting expectations [10]. Therefore, the stakeholder theory provides a bridge between CSR and financial performance, and the CSR behavior of a business will affect its performance through its stakeholders.

CSR measurement has constantly baffled scholars, mainly because CSR is a task rather than a measurement for business operation clearly from a particular aspect. As a result, the definitions of CSR appear to be diverse. Most of these definitions arise from three dimensions: economic, environmental, and social aspects. For example, McWilliams and Siegel [11] define CSR as actions that appear to further certain social good beyond the firm's interests and that which is required by law. Carrol [12] describes corporate social performance as the three-dimensional integration of CSR, corporate social responsiveness, and social issues. Furthermore, Matten and Moon [13] consider corporate social performance a synonym of CSR, corporate social responsiveness, or any other interaction between business and social environment. In contrast, Frederick [14] explores CSR as a requirement for businesses to monitor the operation of an economic system to meet public expectations. These concepts consider that a company does not target profitability only; it also strives to achieve objectives such as adding environmental and social values [15]. To sum up, according to the notion of CSR in the related studies, the core concept of CSR is 
to reflect the entire obligation of a company to its internal stakeholders and incorporates economic responsibility, public responsibility, and social responsiveness [16].

Waddock and Graves [2] adopt the methodology used by Ullman [17], i.e., eight CSR performance attributes rated by Kinder, Lydenberg, Domini (KLD), and other papers that also use KLD as an indicator of CSR [18,19]. Since no professional organization engages in CSR measurement in Taiwan, most empirical studies employ the businesses that receive the CSR awards presented by the CommonWealth Magazine as the basis for the measurement for CSR achievements. The decision of aggregate measure of outperformance rating is made by experts through multidimensional weighted scoring so that the problem of over-focusing on one dimension is less likely to occur. International indicators and measurement methods are used to select the best corporate citizens in Taiwan based on four major dimensions: corporate governance, corporate commitment, social participation, and environmental protection. Corporate governance primarily measures the independence of the board of directors and the company's transparency. Corporate commitment includes a commitment to consumers, nurturing and caring for employees, and investment in innovation and research. Social participation measures a company's long-term commitment to a specific issue and its impact. Financially, environmental protection explores whether a company has specific goals and practices in environmental protection and energy conservation.

\subsection{Relationship between CSR and Financial Performance}

Financial performance is measured on both the accounting basis and the stock price basis (also known as the market basis). The stock price basis measures the extent to which a company's socially responsible conduct leads to greater stock returns, or an event study can be used to observe the abnormal returns before and after a CSR violation event. Most studies, however, use accounting-based metrics as a tool to measure corporate financial performance. Griffin and Mahon [3] summarize 51 previous studies and conclude that the five most commonly measured variables in past studies are: size, return on assets, return on equity, asset age (fixed net assets/gross fixed assets), and five-year return on sales. Theories that explain the positive or negative correlation between social responsibility and financial performance include the negative correlation theory: focus shift hypothesis; positive correlation theory: stewardship theory, redundant resources theory [2] and social impact hypothesis [20]. Some scholars suggest that CSR contributes positively to financial performance. For example, Kim et al. [1] investigated whether the assurance of CSR reports has an impact on the correlation between CSR performance and a firm's financial performance. The results show that the assurance of CSR reports will enable firms themselves to reduce their financial costs by lowering the discount rate for investors, which will in turn improve their financial performance. Cho, Chung, and Young [21] collected 191 sample firms listed on the Korea Exchange (KEJI) to explore the impact of CSR on financial performance. They found that CSR has a partial positive correlation with a firm's financial performance proxied by return on assets and its firm value measured using Tobin's Q. Uadiale and Fagbemi [22] explored the effect of CSR activities on financial performance measured by return on equity (ROE) and return on assets (ROA) by using a sample of 40 audited financial statements of listed companies in Nigeria. Their results indicate that CSR has a positive and significant influence on these financial measures.

However, some empirical studies show an unclear correlation, further suggesting that CSR is driven by unobservable corporate characteristics rather than financial performance [23]. Margolis and Walsh [24] reviewed 18 papers in the previous CSR literature and found that only $53 \%$ of these papers show a positive correlation between CSR and financial performance, indicating an unclear relationship between these two variables. Cho et al. [21] documented a contradiction of previous empirical findings on the impact of CSR on financial performance. Furthermore, Cherian, Umar, Thu, Nguyen-Trang, Sial, and Khuong [25] adopted secondary data from 50 Indian manufacturing firms from 2011 to 2017 and analyzed the impact of CSR reporting on their financial performance. They discovered an adverse impact on the value of a firm resulting from the announcement of 
the CSR act, which is more pronounced than the $2 \%$ expenditure requirement, indicating a negative impact on companies from the disclosure requirement to comply with laws and regulations. Those who argue that there is a negative correlation between CSR and financial performance point out that a higher level of CSR leads to a greater economic burden on the company than other companies with a lower level of CSR [26]. Expenditures other than profitability may lead to inefficiencies in the market, which in turn may reduce overall social efficiency. Furthermore, some researchers have tried to include other variables such as advertising costs, $R \& D$ costs [11], industry growth rate [27], stakeholder ethical values [28], and intangible resources [29] to explain the inconsistency between the contradictory theoretical perspectives in the literature and the empirical results.

Moreover, some scholars believe that CSR and financial performance are not related. For example, Waddock et al. [2] state that the insignificant results may indicate the facts that many variables in the relationship between social and financial performance make their relations coincidental. McWilliams and Siegel [11] assume that there are two firms that produce identical goods, except that one company adds a social characteristic to its product. They show that, in equilibrium, both will be equally profitable. Ullmann [17] emphasize that there is no clear trend in the linkage among social messages, social performance and economic outcomes. The main reasons for this appear to be the inadequacy of the theory, improper definition of key words and a lack of historical evidence. It has been observed that not only social performance and economics but also "messages" about social performance are important, but only a few studies have analyzed the relationship among the three components.

In the past, various theories have been proposed in the literature, but the impact of CSR on corporate performance remains unclear. Extant studies rarely include the functions of mediation and moderation variables to explain the relationship between CSR and corporate performance. Recently, some studies have begun to find a clearer path for CSR's impact on financial performance by applying mediation variables. For example, Lin et al. [16] adopted intellectual capital as a mediation variable and industry category as a moderation variable to explain the effect of CSR on financial performance. Their empirical results show that intellectual capital has a mediation effect on the relationship between CSR and financial performance, while the industry category moderates the direct effect of CSR on financial performance.

\subsection{CSR and Employee Turnover}

The Global Sullivan Principles provide a clear norm that employees are important internal stakeholders in a company. Established in 1977 by African-American minister Leon Sullivan to promote CSR, the Principles call for legal compliance and responsible behavior of businesses, and long-term integration of the principles into corporate business strategies, including corporate policies, procedures, training and internal reporting, and a commitment to follow them. If a company's employee-oriented social responsibility behavior is based on the Global Sullivan Principles, we can reasonably infer that there will be higher employee satisfaction. According to previous studies, a company's engagement in CSR activities changes the employees' perceptions of the company [30]. Since employee satisfaction is more difficult to observe and quantify, the data are limited. Regarding that the employee turnover or its fluctuation level may be lower than the average of the same industry for the companies with higher employee satisfaction, this study uses employee turnover as a proxy for employee satisfaction. Previous studies mostly involved surveys in the form of questionnaires on the employees' perceptions of the company's CSR activities. However, the ultimate expression of employee satisfaction with the company is whether they stay in the company or not. Therefore, this study uses employees' actual behavioral decisions as the basis of measurement and analyzes the impact of CSR on employee satisfaction through employee turnover.

Previous literature may benefit from a direct exploration of the relationship between CSR and employee turnover, but good employee relations can boost morale, increase 
employee satisfaction, and make it easier to retain good employees. When employees are being recruited, it is easier for a socially responsible company to recruit employees. For example, Marriott supports community service organizations and brings together philanthropic investments and internal programs to significantly reduce the company's cost of recruiting lower-level employees. Moreover, community service organizations refer the chronically unemployed to Marriott, which provides $180 \mathrm{~h}$ of free classes and on-the-job training for the unemployed. As a result, $90 \%$ of those who have been trained have joined Marriott, and the retention rate after one year is well above average [31].

Some scholars call for a more precise theoretical explanation of the relationship between CSR and financial performance to clarify the processes involved and identify important mediation conditions [10,32-35]. Therefore, existing theories and data do not provide clear answers to some of the key questions about CSR. One way to understand the impact of CSR on corporate costs and benefits is to examine the impact of CSR on employees. Previous studies typically focused on how CSR affects important stakeholders, particularly investors [36] and consumers [37], but overlooks employees [32,33].

Research on employees also indicates that CSR has many positive effects on attitudes toward a company and workplace behavior, including organizational pride, satisfaction, commitment, in role performance, organizational citizenship behavior, and turnover intentions [38-45]. Carmeli, Gilat, and Waldman [46] surveyed employees and supervisors at four electronics and media industry companies. They found that the employees' understanding of social responsibility contributed to increased recognition of their organization, which in turn improved the supervisors' evaluation of employees' performance, providing the direct evidence that CSR can lead to organizational recognition. Moreover, Jones [41] similarly found that employees' attitudes about a volunteerism program are positively correlated to organizational pride and identification, which in turn predicted the employees intentions to remain with the organization, organizational citizenship behavior, and in-role performance six months later. The results of these two studies provide the best evidence that CSR is involved in the social identity process and affects the relationship between employees and their organization.

In summary, a company's implementation of CSR enhances its corporate image and reputation. CSR is like a piece of information, and employees regard the practice of CSR as a basis for "whether the company can be trusted and entrusted".

\subsection{Employee Turnover and Financial Performance}

Regarding the relationship between employee turnover and financial performance, the literature suggests that if a company wants to achieve long-term financial growth, it must invest more in its employees, systems, and organizational process capabilities [47]. Koys [48] argues that employee satisfaction, organizational citizenship behavior, and employee turnover in the previous period might affect the corporate profitability and customer satisfaction in the next period. The empirical results show that corporate citizenship behavior in the previous period is significantly correlated to the profitability in the next period.

Employees have long been viewed as critical organizational assets that create value [49] and are important to a company's innovation and quality [50]. Edmans [51] used the annual survey data of the "100 Best Companies to Work For in America" as an indicator of employee satisfaction, and shows that these "Best Companies" have annual stock price returns that beat the market by two to three percent per year during the 26 years from 1984 to 2009. Moreover, disruptions in existing jobs [52] and loss of accumulated experience due to employee turnover [53] can cause the employees to leave the company, resulting in declining corporate performance. The reasons for poor corporate performance include the direct costs of employment termination, such as discharge, recruitment of new employees, and training costs for new employees [54,55]. Ton and Huckman [56] analyzed employee turnover data for major retail chains in the U.S. and found that, on average, employee turnover is linked to the decline of corporate performance, measured by profit margin 
and customer service. Grennan [57] constructed measures of corporate culture based on employee reviews of the firm and found that corporate culture is positively correlated with long-term firm value in this context. Moreover, employee turnover is associated with some indirect costs, such as the disruption of work in progress as key employees leave [58]. Other sources of indirect costs include the demoralization of the company's employees, which may be caused by the loss of a respectable colleague, or by the fact that the departing colleague's work is taken on by other employees whose abilities have been depleted [59].

Furthermore, employee satisfaction may be a valuable intangible asset of a company and affects its performance. Employees are important assets of a company. Improvement to the work efficiency of the employees contributes to improved financial performance. Such improvement itself depends on the improvement of non-financial indicators. Therefore, non-financial indicators also play an important role in financial performance. Huang, Li, Meschke, and Guthrie [60] explored the impact of employee satisfaction on firm value based on human resource management theories with family firms as an example. They found that the organizational form affects the employees' perceptions of career and top management, and the employees' perceptions of the company and leadership further affect corporate performance. Various types of employee satisfaction, such as empowerment, job fulfillment, security, pay, and work team, have a positive impact on a company's financial performance measured by return on assets and earnings per share [61]. The research of Yoo, Choi, and Chon [62] also suggests that CSR affects accounting profitability by enhancing employee commitment.

In this study, we conjecture that if employees' perceptions of the company can be improved and if they can be satisfied through the employee component of CSR to enhance employee satisfaction and reduce employee turnover, the company's financial performance can be further improved as a result. The mediation model is more commonly used in fields related to human resources or organizational behavior. However, based on the empirical results of CSR and financial performance, there is no definite theory in the literature. Previous studies have primarily investigated CSR's impact on, or association with, corporate financial performance without distinguishing between internal and external factors. In contrast, this study further explores the correlation between these two through employee satisfaction as an internal factor. Thus, this study is based on the stakeholder theory and attempts to explain CSR's impact on financial outcomes through the mediation role of employee satisfaction.

\section{Research Hypothesis}

Our first research question is regarding the relationship between CSR and employees. While the relationship between CSR and financial performance and the potential influence mechanisms between them are not yet conclusive, this study aims to apply the stakeholder theory to explain the relationship. Regarding employees as important internal stakeholders of a business, this study hypothesizes that the employee component can be used to mediate "how CSR affects financial performance". The companies with a strong reputation for CSR typically exhibit cooperative rather than opportunistic behavior across stakeholder relationships, so CSR may help to satisfy the need for security and safety. Employees can then infer from CSR that their company is ethical and it is safe to devote time and energy to the company. In other words, CSR can serve as the basis of presumptive trust [7]. Therefore, CSR can improve people's understanding of corporate ethics, which in turn can help to satisfy employees' needs for security, self-esteem, belongingness, and a meaningful existence.

According to academic and practical research, the factors that affect the strategic application of CSR include alignment with business and corporate culture as well as with social needs and sincerity [63]. Once these factors are satisfied, employees will perceive CSR activities more positively and proactively. Increased productivity [64], reduced employee shirking [65], and increased retention [66] are important employee benefits associated with CSR investments, through which the altruistic impact of CSR investments can reduce em- 
ployee turnover. Carnahan, Kryscynski, and Olson [67] conducted a study on whether the companies more actively engaged in CSR could better retain their employees after the 911 terrorist attacks in the U.S. Employee awareness of CSR activities plays an important role internally in improving loyalty and reducing employee turnover. Lee, Park, and Lee [68] conducted a study on how employees perceive CSR-related activities conducted by their employers, and their findings indicate that CSR behavior affects employees' perceptions of CSR, and in turn enhances employees' reliance on their companies and their performance. Yasin, Namoco, Jauhar, Rahim, and Zia [30] investigated whether the ethical aspects of corporate leadership reduce employees' intention to leave the company and found that responsible leadership is positively correlated with the internal ethical climate within the company, which is negatively correlated with the employee turnover of the company.

Several prior studies have shown that employee satisfaction becomes greater in the companies that have implemented CSR. Since employee morale and satisfaction are difficult to measure, we use employee turnover as a proxy variable for CSR in the quality of employee relationship management, and construct our first hypothesis as follows:

Hypothesis 1a (H1a). The firms that focus more on CSR have significantly lower employee turnovers than the control firms in the same industry.

Hypothesis $\mathbf{1 b}$ (H1)). The firms that focus more on CSR have significantly more stable employee turnovers than the control firms in the same industry.

Satisfying and being accountable to the stakeholders, i.e., shareholders, employees, suppliers, community, environment, etc., may actually have a significant impact on the scale of a company, especially in financial terms [2,69]. An important aspect of the balanced scorecard is to illustrate the linkage between non-financial indicators, e.g., employee satisfaction and customer satisfaction, and financial indicators of performance. Prior literature builds strategic models such as the Sustainability Balanced Scorecard (SBSC) to represent a bridge from the sustainability dimensions to the performance management system (PMS), aiming to create value and, therefore, improve the company's performance [70]. Banker, Konstans, and Mashruwala [71] focused on employee satisfaction and explain its impact on financial performance, presenting the direct impact of employee satisfaction on costs and revenues and an indirect impact through the correlation with employee satisfaction.

Different types of companies, as well as different industries, may place differential importance on CSR. The environmental sensitivity of industries affects CSR disclosure, and the companies in environmentally sensitive industries are more likely to disclose their environmental performance [72]. The companies in the financial and service industries are more likely to disclose social issues and donation-related behaviors than other industries [73]. Another study is conducted on the trend of CSR disclosure in mining-related industries. Jenkins and Yakovleva [74] suggest that, in general, industries including mining, petroleum, and chemical companies, emphasize environment, health, and safety. This shows that companies in different industry categories have different views on CSR and focus on different aspects. The disclosure of CSR varies from industry to industry and is related to the costs and benefits associated with different industry characteristics [16].

Given the characteristics of an industry, the companies that are less well known to the public or are in a supply chain that does not pay more attention to CSR, their CSR contributions may be less pronounced to the market. However, good employee relations are felt by employees, and employees are more aware of CSR-oriented activities and can even participate. As mentioned above, this is related to employee loyalty, morale, retention, and productivity, which in turn affect financial performance and make it better than that of the other companies in the same industry. Accordingly, we construct the following hypotheses.

Hypothesis 2a (H2a). The firms with lower employee turnovers financially outperform the control firms in the same industry. 
Hypothesis $\mathbf{2 b} \mathbf{(} \mathbf{H} \mathbf{2 b})$. The firms with stable employee turnovers in the previous period financially outperform the control firms in the same industry.

Regarding the linkage between CSR and financial performance through the stakeholder theory, a study by Cornell and Shapiro [75] shows that the value of a company depends on both the explicit and implicit costs of debt. They indicate that if a company does not operate in a socially responsible manner, implicit contracts related to CSR may contribute to converting these implicit contracts into explicit contracts, which will bring higher costs to the company. Moreover, socially irresponsible behavior may spill over to other implicit stakeholders skeptical that the company will live up to its claims. Thus, the companies with higher CSR may find that they have lower cost hidden claims than other companies and have better financial performance.

A study by Yoo, Choi, and Chon [63] utilizes social identity theory (SIT) to describe how CSR strengthens the relationship between the employees and the organization, which in turn contributes to the company's financial performance. The willingness of employees to leave the organization voluntarily and permanently is regarded as the intention to leave [76], and employee turnover also causes incremental costs to the organization, such as the cost of discharging old employees, the cost of recruiting new employees, and the cost of training, which are additional burdens to the company and further affect its financial performance. Accordingly, this study views employee satisfaction or employee turnover as a mediation factor for CSR's impact on financial performance.

If CSR can be reflected in financial performance, we can attribute the impact to external or internal factors. External factors come from the industry characteristics, government regulations, community interactions, and consumer perceptions of each company, while internal factors mainly pertain to employee relations. External factors affect financial performance by revenue, e.g., supply chain requirements, the tendency of consumers with CSR awareness to buy, and higher customer satisfaction and cost, e.g., smaller costs caused by governments or communities, such as pollution fines and community protests. Moreover, internal factors such as employee relations affect productivity, e.g., higher efficiency or quality, e.g., a lower return rate of goods, affecting financial performance. However, the empirical literature does not explore this area and rarely mentions employee factors. As a result, some empirical findings on the relationship between social responsibility and performance are not significant and subtly remind us that performance is not instantly predictable. For example, if a vendor is in a midstream or upstream supply chain and has little interaction with end consumers, the price will be the primary consideration of its customers' purchases, and customer satisfaction may not necessarily rise with CSR at this time. Therefore, this paper adopts Taiwanese companies, mainly in the middle or upper reaches of the supply chain, for the sample and employee turnover as the mediation factor to clarify the relationship between CSR and financial performance. However, it will be difficult to conclude if the results are insignificant because of the lack of direct relationship, model design, and data sampling bias. Therefore, this study uses a sensitivity test to eliminate modeling and sampling issues as much as possible. Based on the above arguments, our hypothesis in this section is provided as follows:

Hypothesis 3 (H3). When employee turnover serves as the mediation variable, with a control of industry characteristics, the impact of CSR on financial performance becomes significant.

Previous studies primarily focused on CSR's impact on, or connection to, corporate financial performance, while this study focuses on the mediation effect of employee relations. The companies that value CSR care about the quality of their employees' work and make them feel satisfied with the companies. Therefore, this study suggests that employee turnover plays a mediation role between CSR and corporate financial performance after industry characteristics are incorporated in the framework of the mediation model. If the relationship of this study is confirmed, it adds to the literature to clarify the causal relationship between CSR and financial performance. 


\section{Sample Data and Research Design}

There is no comprehensive CSR evaluation of the companies in Taiwan. The Taiwan Stock Exchange (TSE) launches the Taiwan Employment 99 Index at the end of 2010, using a single "number of employees" as a CSR evaluation item in the hope of achieving a win-win situation for both CSR and return on investment. However, the "socially responsible enterprises" selected by the TSE based on only one indicator may be different from the general public's perception. In 2007, CommonWealth Magazine starts to select the CommonWealth Top 50 Corporate Citizens, while Global Views Monthly presents the first CSR Award in 2005. The evaluation is conducted by experts from different aspects for both magazines and is more comprehensive than the TSE's. This study extensively explores CSR and employee reactions, and aims at supplementing the inadequacy of employee reactions in evaluating CSR at this stage.

\subsection{Sample Descriptions and Control Group Selection \\ 4.1.1. Sample Descriptions}

This study forms an experimental group of the companies that received the CommonWealth Corporate Citizenship Award from CommonWealth Magazine from 2007 to 2018. The CommonWealth Magazine uses four aspects: corporate governance, corporate commitment, social participation, and environmental protection, to evaluate whether a company has CSR. Not confined to Taiwan's companies listed on the Taiwan Stock Exchange or Taipei Exchange, CommonWealth Corporate Citizen Awards are conferred upon foreign companies and state-owned enterprises as well. Because of the limitation in obtaining financial information about the Taiwan branches of foreign companies and state-owned enterprises, they are excluded from the sample of this study. We also exclude a few of the awarded companies that are subsidiaries of another company because their financial information is publicly unavailable. Furthermore, some of the award winners are group companies, such as Formosa Plastics Group, and only the most representative companies within the group (in this case, Formosa Plastics Corp.) are included in the sample of this study.

We classify all award-winning companies in 2007 into three groups according to their total assets. The first group consists of the financial sector, which has significantly higher total assets than the other two groups, and the other two groups are large companies with greater total assets and medium-sized companies with fewer assets. Moreover, we take the natural logarithm of the assets of all firms for two reasons. The first reason is that we find that the total assets in both the winning group and the market as a whole are not normally distributed and have significant variation. Therefore, the variability of the assets after taking the natural logarithm can be substantially reduced and are normally distributed, which is convenient for the subsequent selection of the controlled sample firms. Another reason is still the nature of the natural logarithm. Therefore, although the companies with greater total assets positively impact financial performance when predicted, the positive influence will become less significant as the assets get higher because the natural logarithm is a concave function and decreases in shape. This is also consistent with the general law of diminishing marginal utility in economics.

\subsubsection{Control Group Design}

For comparison purposes, this study selects the control firms of the non-awardwinners in each period to explore whether the award-winners have significant outperformance in terms of financial performance or employee reactions. This study applies a systematic selection procedure for the control group selection. This study chooses assets as the selection criterion because the companies that win the awards need to accumulate a certain amount of resources. However, if they have accumulated and achieved a certain extent of resources but do not win the awards, these companies cannot use the excuses of insufficient resources or satisfy their shareholders' demands at the expense of other 
stakeholders. Therefore, it is meaningful to use assets as one of the selection criteria to screen the control group rather than randomly selected ones.

The criteria for selecting the control group in this study are primarily derived from the analysis of award-winners. The selection process states below.

(1) Financial holding companies are excluded from the award winners because their nature is different from other companies and their assets are too large compared with the other companies to the extent that the design selection criteria would be overestimated.

(2) After the natural logarithm of the assets of the remaining winners is taken, the mean and standard deviation are calculated.

(3) Furthermore, the mean value minus one standard deviation is used as the selection criterion, and non-awarded companies whose natural logarithm of the assets are above the selection criterion are selected for the control group.

\subsubsection{Treatment of Extreme Values}

This study conducts multiple regression methods to test the hypotheses, however, the estimation results of the model will be affected if there are extreme values in the variables. Therefore, all variables used in this study are winsorized at the 1st and 99th percentiles. The financial and accounting information and employee turnover are obtained from the Taiwan Economic Journal Database, and the industry is defined by the industry classification of the Directorate-General of Budget, Accounting and Statistics (DGBAS) of the Executive Yuan.

\subsection{Research Variables}

\subsubsection{CSR Performance}

CSR performance is multi-faceted, and therefore this study applies the CommonWealth Corporate Citizen Award of the CommonWealth Magazine as the CSR indicator.

\subsubsection{Financial Performance and Control Variables}

Based on previous literature $[2,3,77]$, this study uses return on assets $\left(\mathrm{ROA}_{i, t}\right)$ and return on equity $\left(\mathrm{ROE}_{\mathrm{i}, \mathrm{t}}\right)$ as variables of financial performance. As for the control variables, size, industry, number of years of establishment, and prior financial performance are selected.

\subsubsection{Employee Satisfaction}

This study adopts the employee turnover rates published by the Taiwan Economic Journal as the indicator of employee satisfaction. The method we use to calculate the employee turnover is derived from Lin and Jung [78].

\subsection{Model Framework and Empirical Models}

Baron and Kenny [79] propose that for a variable to play the role of a mediation variable, the following three conditions must be met (see Figure 1): (1) the change of the independent variable can significantly account for the change of the hypothetical mediation variable, i.e., path a in Figure 1, (2) the change of the mediation variable can significantly account for the change of the dependent variable, i.e., path $b$ in Figure 1, and (3) when paths a and b are controlled, the previously significant relationship between the independent variable and the dependent variable is no longer significant. When path $\mathrm{c}$ is a zero relationship, the mediation has the strongest impact. From the perspective of path analysis, the analysis is to check whether the two variables are incorrectly correlated. For example, Figure 1 shows that the independent variable $X$ correlates with the dependent variable $\mathrm{Y}$. However, the truth is, $\mathrm{X}$ influences $\mathrm{Y}$ through the mediation variable $\mathrm{M}$. 


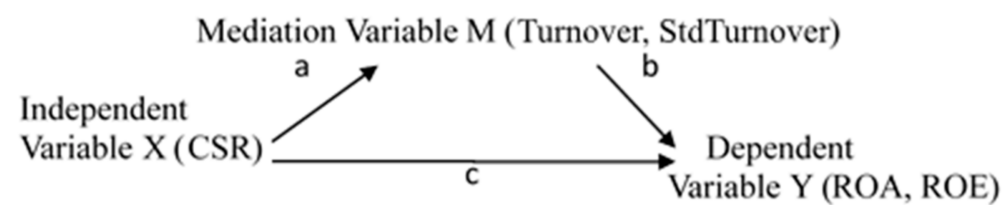

Figure 1. The framework of mediation model.

This study uses a mediation model framework to examine our hypotheses. Compared to the mediation model or path analysis approach, which both require the independent variables to be able to explain the dependent variables, this study conjectures that CSR is multi-faceted and difficult to measure, and the process of affecting financial performance is more influenced by external factors. As a result, the empirical results of previous literature are not clear. Therefore, the model framework reflects the inference of this study that the direct impact of CSR on financial performance is insignificant.

Following the methodology of Ruf et al. [77], we examine whether CSR-conscious firms have a significantly lower employee turnover than those of the control firms in the same industry due to a better relationship with their employees, i.e., the H1a hypothesis. This study adopts a cross-period regression model based on the assumption that if a company's assumption of social responsibility is recognized, this should have a positive effect on employee satisfaction. Our model controls the industry and year fixed effects. The regression model is designed as follows.

Turnover $_{i, t}=\alpha_{0}+\alpha_{1}$ CSR $_{\mathrm{i}, \mathrm{t}-1}+\alpha_{2}$ Size $_{\mathrm{i}, \mathrm{t}}+\alpha_{3}$ Age $_{\mathrm{i}, \mathrm{t}}+\alpha_{4} \operatorname{IndusDum}_{\mathrm{i}, \mathrm{t}}+\alpha_{5}$ YearDum $_{\mathrm{i}, \mathrm{t}}+\varepsilon_{\mathrm{i}, \mathrm{t}}$,

where Turnover ${ }_{i, t}$ is the employee turnover of company $i$ in the current period (period $t$ ); $\mathrm{CSR}_{\mathrm{i}, \mathrm{t}-1}$ is the dummy variable and equals one if the company is a CSR company in the previous period and zero otherwise; the control variables, $S_{i z e_{i, t}}$ is the size of company $i$ in the current period, measured by the logarithm of assets; Age $e_{i, t}$ is the number of years from the establishment of company $i$ to the current period; IndusDum $i, t$ is the industry dummy variable; YearDum $i, t$ is the year dummy variable and $\varepsilon_{i, t}$ is the residual term.

Furthermore, we use the following regression model to test if the employee turnover of socially responsible enterprises is less frequent than that of the control observations in the same industry, i.e., the hypothesis H1b.

StdTurnover $_{\mathrm{i}, \mathrm{t}}=\alpha_{0}+\alpha_{1}$ CSR $_{\mathrm{i}, \mathrm{t}-1}+\alpha_{2}$ Size $_{\mathrm{i}, \mathrm{t}}+\alpha_{3}$ Age $_{\mathrm{i}, \mathrm{t}}+\alpha_{4} \operatorname{IndusDum}_{\mathrm{i}, \mathrm{t}}+\alpha_{5} \operatorname{YearDum}_{\mathrm{i}, \mathrm{t}}+\varepsilon_{\mathrm{i}, \mathrm{t}}$,

where StdTurnover $i, t$ is the standard deviation of employee turnover of company $i$ from the previous period to the current period (i.e., period $t$ ); $\mathrm{CSR}_{\mathrm{i}, \mathrm{t}-1}$ is the dummy variable and equals one if the company is a CSR company in the previous period and zero otherwise. In the control variables, Size $_{i, t}$ is the size of company $i$ in the current period, measured by the logarithm of assets; Age $_{i, t}$ is the number of years from the establishment of company $i$ to the current period; IndusDum $i, t$ is the industry dummy variable; YearDum $i, t$ is the year dummy variable and $\varepsilon_{i, t}$ is the residual term.

We further examine if firms with a lower employee turnover in the previous period might have a better financial performance on an accounting basis than the control firms in the same industry, i.e., the $\mathrm{H} 2 \mathrm{a}$ hypothesis. The model is listed as follows.

Fin $_{\mathrm{i}, \mathrm{t}}=\alpha_{0}+\alpha_{1}$ Turnover $_{\mathrm{i}, \mathrm{t}}+\alpha_{2}$ Fin $_{\mathrm{i}, \mathrm{t}-1}+\alpha_{3}$ Age $_{\mathrm{i}, \mathrm{t}}+\alpha_{4}$ Size $_{\mathrm{i}, \mathrm{t}}+\alpha_{5}$ IndusDum $_{\mathrm{i}, \mathrm{t}}+\alpha_{6}$ YearDum $_{\mathrm{i}, \mathrm{t}}+\varepsilon_{\mathrm{i}, \mathrm{t}}$,

where $\varepsilon_{\mathrm{i}, \mathrm{t}} \sim \mathrm{WN}\left(0, \sigma^{2}\right)$ and $\mathrm{E}\left(\varepsilon_{\mathrm{t}} \mathrm{Fin}_{\mathrm{t}-\mathrm{j}}\right)=0, \forall \mathrm{j}>0$; the dependent variable Fin $\mathrm{i}_{\mathrm{t}, \mathrm{t}}$ includes the return on assets, and return on equity of company $i$ in the current period; Turnover $i \cdot t$ is the employment turnover of company $\mathrm{i}$ in the period $\mathrm{t}$. In the control variables: $\mathrm{Fin}_{\mathrm{i}, \mathrm{t}-1}$ is the return on assets, and return on equity of company $i$ in the previous period; Age $_{i, t}$ is the number of years from the establishment of company $i$ to the current period; Size $_{i, t}$ is the size of company $i$ in the current period, measured by the logarithm of assets; IndusDum $_{i, t}$ is the industry dummy variable; YearDum ${ }_{i, t}$ is the year dummy variable and $\varepsilon_{i, t}$ is the residual term. 
We further test the hypothesis $\mathrm{H} 2 \mathrm{~b}$ by examining if firms with a stable employee turnover have better financial performance on an accounting basis than control observations in the same industry. The regression model is provided as follows:

Fin $_{\mathrm{i}, \mathrm{t}}=\alpha_{0}+\alpha_{1}$ StdTurnover $_{\mathrm{i}, \mathrm{t}}+\alpha_{2}$ Fin $_{\mathrm{i}, \mathrm{t}-1}+\alpha_{3}$ Age $_{\mathrm{i}, \mathrm{t}}+\alpha_{4}$ Size $_{\mathrm{i}, \mathrm{t}}+\alpha_{5} \operatorname{IndusDum}_{\mathrm{i}, \mathrm{t}}+\alpha_{6}$ YearDum $_{\mathrm{i}, \mathrm{t}}+\varepsilon_{\mathrm{i}, \mathrm{t}}$

where $\varepsilon_{i, t} \sim \mathrm{WN}\left(0, \sigma^{2}\right)$ and $\mathrm{E}\left(\varepsilon_{\mathrm{t}} \mathrm{Fin}_{\mathrm{t}-\mathrm{j}}\right)=0, \forall \mathrm{j}>0$; the dependent variable Fin ${ }_{\mathrm{i}, \mathrm{t}}$ includes the return on assets, and return on equity of company $i$ in the current period; StdTurnover $r_{i, t}$ is the standard deviation of the employee turnover of company i from the previous period to the current period. In the control variables, Fin $_{\mathrm{i}, t-1}$ is the return on assets, and return on equity of company $i$ in the previous period; Age $_{i, t}$ is the number of years from the establishment of company $i$ to the current period; Size $e_{i, t}$ is the size of company $i$ in the current period, measured by the logarithm of assets; IndusDum $\mathrm{i}_{\mathrm{i}, \mathrm{t}}$ is the industry dummy variable; YearDum $\mathrm{i}_{\mathrm{i}, \mathrm{t}}$ is the year dummy variable and $\varepsilon_{\mathrm{i}, \mathrm{t}}$ is the residual term.

Finally, to examine the third hypothesis, we use Equations (5)-(7) to examine if CSR has a significant effect on a firm's financial performance after the employee turnover is used as a mediation variable and industry characteristics are controlled.

$$
\begin{aligned}
& \operatorname{Fin}_{\mathrm{i}, \mathrm{t}}=\alpha_{0}+\alpha_{1} \operatorname{CSR}_{\mathrm{i}, \mathrm{t}-1}+\alpha_{2} \operatorname{Fin}_{\mathrm{i}, \mathrm{t}-1}+\alpha_{3} \operatorname{Age}_{\mathrm{i}, \mathrm{t}}+\alpha_{4} \operatorname{Size}_{\mathrm{i}, \mathrm{t}}+\alpha_{5} \operatorname{IndusDum}_{\mathrm{i}, \mathrm{t}}+\alpha_{6} \text { YearDum }_{\mathrm{i}, \mathrm{t}}+\varepsilon_{\mathrm{i}, \mathrm{t}}, \\
& \text { Fin }_{\mathrm{i}, \mathrm{t}}=\alpha_{0}+\alpha_{1} \text { Turnover }_{\mathrm{i}, \mathrm{t}}+\alpha_{2} \mathrm{CSR}_{\mathrm{i}, \mathrm{t}-1}+\alpha_{3} \text { Fin }_{\mathrm{i}, \mathrm{t}-1}+\alpha_{4} \text { Age }_{\mathrm{i}, \mathrm{t}}+\alpha_{5} \text { Size }_{\mathrm{i}, \mathrm{t}} \\
& +\alpha_{6} \text { IndusDum }_{\mathrm{i}, \mathrm{t}}+\alpha_{7} \text { YearDum }_{\mathrm{i}, \mathrm{t}}+\varepsilon_{\mathrm{i}, \mathrm{t}} \text {, and } \\
& \text { Fin }_{\mathrm{i}, \mathrm{t}}=\alpha_{0}+\alpha_{1} \text { StdTurnover }_{\mathrm{i}, \mathrm{t}}+\alpha_{2} \mathrm{CSR}_{\mathrm{i}, \mathrm{t}-1}+\alpha_{3} \text { Fin }_{\mathrm{i}, \mathrm{t}-1}+\alpha_{4} \text { Age }_{\mathrm{i}, \mathrm{t}} \\
& +\alpha_{5} \text { Size }_{\mathrm{i}, \mathrm{t}}+\alpha_{6} \text { IndusDum }_{\mathrm{i}, \mathrm{t}}+\alpha_{7} \text { YearDum }_{\mathrm{i}, \mathrm{t}}+\varepsilon_{\mathrm{i}, \mathrm{t}} \text {, }
\end{aligned}
$$

where $\varepsilon_{i, t} \sim \mathrm{WN}\left(0, \sigma^{2}\right)$ and $\mathrm{E}\left(\varepsilon_{\mathrm{t}} \mathrm{Fin}_{\mathrm{t}-\mathrm{j}}\right)=0, \forall \mathrm{j}>0$; the dependent variable Fin $\mathrm{i}_{\mathrm{i}, \mathrm{t}}$ includes the return on assets $\left(\mathrm{ROA}_{i, t}\right)$ and return on equity $\left(\mathrm{ROE}_{i, t}\right)$ of company $i$ in the current period; $\operatorname{CSR}_{\mathrm{i}, \mathrm{t}-\mathrm{1}}$ is the dummy variable and equals one if the company is a CSR company in the previous period and zero otherwise. In the control variables, Fin $_{i, t-1}$ is the corresponding financial performance of company $i$ in the previous period, i.e., either $R A_{i, t-1}$ or $R O E_{i, t-1}$ of company $i$ in the previous period; $A e_{i, t}$ is the number of years from the establishment of company $i$ to the current period; Size $e_{i, t}$ is the size of company $i$ in the current period, measured by the logarithm of assets; IndusDum $\mathrm{i}_{\mathrm{i}, \mathrm{t}}$ is the industry dummy variable; YearDum $\mathrm{i}, \mathrm{t}$ is the year dummy variable and $\varepsilon_{i, t}$ is the residual term.

\section{Research Results}

Table 1 presents sample descriptive statistics and the coefficients of correlations among variables used in this study. We form the experimental group of firms that receive the CommonWealth Corporate Citizenship Award from CommonWealth Magazine from 2007 to 2018. Panel A illustrates the industry distribution of CSR firms. The industry distribution of CSR firms includes a greater proportion of observations from manufacturing, financial and insurance activities, and real estate activities industries. Panel B of Table 1 reports the summary statistics of financial performance, i.e., ROA and ROE, employee turnover (Turnover), employee turnover variability (StdTurnover), Age, Size, and CSR for socially responsible companies, i.e., awarded with the CommonWealth Corporate Citizen Award, and control group ones, i.e., not awarded with the CommonWealth Corporate Citizen Award. The sample period is from 2007 to 2018. Our sample period including the global financial crisis in 2008, which resulted in significant changes in revenues or earnings, significant variance in financial performance variables took place as a result. Although the variance is partly due to systematic risk, it can still seriously affect the estimation results when regression analysis is performed. Therefore, this study adopts the winsorizing method to mitigate the effect of either influential points, outliers, or both, on the regression model and controls the industry and year fixed effects. 
Table 1. Sample descriptive statistics. This study forms the experimental group of firms that received the CommonWealth Corporate Citizenship Award from CommonWealth Magazine from 2007 to 2018. Panel A illustrates the industry distribution of observations. Panel B presents the descriptive statistics of all variables. Panel C presents the coefficients of Pearson (Spearman) correlations among variables, as shown in the lower (upper) triangular matrix. Variables definitions: ROE is the return on equity, ROA is the return on assets, Turnover is the employee turnover, StdTurnover is the standard deviation of employee turnover, measured by the standard deviation of employee turnover over the past five years, $\mathrm{CSR}_{\mathrm{t}-1}$ is the dummy variable and equals one if the company is a company that was awarded the CSR prize during the previous period and zero otherwise, Size is measured by the logarithm of the firm's assets, and Age is the number of years from the establishment to the current period.

\begin{tabular}{|c|c|c|}
\hline \\
\hline \multicolumn{3}{|l|}{$\begin{array}{l}\text { Panel A Industry Distribution } \\
\text { Industry }\end{array}$} \\
\hline Manufacturing & 3505 & $67.5 \%$ \\
\hline Electricity and Gas Supply & 22 & $0.4 \%$ \\
\hline Water Supply and Remediation Activities & 20 & $0.4 \%$ \\
\hline Construction & 109 & $2.1 \%$ \\
\hline Wholesale and Retail Trade & 265 & $5.1 \%$ \\
\hline Transportation and Storage & 183 & $3.5 \%$ \\
\hline Accommodation and Food Service Activities & 37 & $0.7 \%$ \\
\hline Information and Communication & 107 & $2.1 \%$ \\
\hline Financial and Insurance Activities & 587 & $11.3 \%$ \\
\hline Real Estate Activities & 330 & $6.4 \%$ \\
\hline Professional, Scientific and Technical Activities & 11 & $0.2 \%$ \\
\hline Arts, Entertainment and Recreation & 7 & $0.1 \%$ \\
\hline Other Service Activities & 13 & $0.3 \%$ \\
\hline Total & 5196 & $100.0 \%$ \\
\hline
\end{tabular}

\section{Panel B Descriptive Statistics}

\begin{tabular}{|c|c|c|c|c|c|c|c|}
\hline \multicolumn{2}{|c|}{ Variable } & Mean & Std. Dev. & Min. & Max. & $\begin{array}{c}5 \% \\
\text { percentile }\end{array}$ & $\begin{array}{c}95 \% \\
\text { percentile }\end{array}$ \\
\hline \multicolumn{2}{|c|}{ ROA (\%) } & 8.63 & 7.51 & -43.35 & 39.73 & -0.13 & 22.15 \\
\hline \multicolumn{2}{|c|}{ ROE (\%) } & 7.59 & 13.74 & -132.73 & 61.06 & -12.74 & 26.10 \\
\hline \multicolumn{2}{|c|}{ Turnover (\%) } & 10.25 & 11.91 & 0 & 86 & 0 & 33 \\
\hline \multicolumn{2}{|c|}{ StdTurnover } & 6.15 & 6.36 & 0 & 47.12 & 0 & 19.31 \\
\hline \multicolumn{2}{|c|}{$\mathrm{CSR}_{\mathrm{t}-1}$} & 0.10 & 0.30 & 0 & 1 & 0 & 1 \\
\hline \multicolumn{2}{|c|}{ Size (TWD) } & 17.37 & 1.36 & 13.78 & 21.55 & 13.05 & 20.21 \\
\hline \multicolumn{2}{|c|}{ Age (year) } & 32.32 & 16.27 & 2 & 102 & 8 & 61 \\
\hline \multicolumn{8}{|c|}{ Panel C Pearson and Spearman Correlation Matrix } \\
\hline & ROE & ROA & turnover & StdTurnover & $\mathrm{CSR}_{\mathrm{t}-1}$ & Size & Age \\
\hline ROE & 1 & $0.6416^{* * *}$ & $-0.0939^{* * *}$ & $-0.0584^{* * *}$ & $0.1022 * * *$ & 0.0098 & -0.0125 \\
\hline $\mathrm{ROA}$ & $0.6416^{* * *}$ & 1 & $-0.0271 *$ & $-0.0834^{* * *}$ & $0.1312 * * *$ & $-0.1489 * * *$ & $-0.1482 * * *$ \\
\hline turnover & $-0.0939^{* * *}$ & $-0.0271 *$ & 1 & $0.3368^{* * *}$ & $-0.0502 * *$ & $-0.1019 * * *$ & $-0.1197^{* * *}$ \\
\hline StdTurnover & $-0.0584^{* * *}$ & $-0.0834^{* * *}$ & $0.3368^{* * *}$ & 1 & $-0.0414^{* * *}$ & $-0.0661^{* * *}$ & $-0.0635^{* * *}$ \\
\hline $\mathrm{CSR}_{\mathrm{t}-1}$ & $0.1022^{* * *}$ & $0.1312^{* * *}$ & $-0.502^{* *}$ & $-0.0414^{* *}$ & 1 & $0.1843^{* * *}$ & $-0.0357^{* *}$ \\
\hline Size & 0.0098 & $-0.1489^{* * *}$ & $-0.1019^{* * *}$ & $-0.0661^{* * *}$ & $0.1843^{* * *}$ & 1 & $0.0067^{* * *}$ \\
\hline Age & -0.0125 & $-0.1482^{* * *}$ & $-0.1197^{* * *}$ & $0.0635^{* * *}$ & $-0.0357^{* *}$ & 0.0067 & 1 \\
\hline
\end{tabular}

$*, * *$, and ${ }^{* * *}$ denote the two-tailed significance levels of $5 \%, 1 \%$, and $0.1 \%$, respectively.

Panel C presents the coefficients of Pearson (Spearman) correlations among variables, as shown in the lower (upper) triangular matrix. Panel $C$ shows that a non-trivial correlation exists between variables, but no significant correlation between the independent variables.

Table 2 compares corporate financial variables and employee turnover between the socially responsible companies and the control observations in the control group. The results show that the return on assets (ROA) and return on equity (ROE) of the socially responsible companies are significantly greater than those of the companies in the control group. However, the employee turnover and the standard deviation of the turnover for CSR firms are significantly less than those for the control group. 
Table 2. Comparison of employee turnover and firm performance between CSR firms and control group. This table compares employee turnover and firm performance between CSR firms (denoted by Good) and control group (denoted by Comp). Turnover is the employee turnover, StdTurnover is the standard deviation of employee turnover, measured by the standard deviation of employee turnover over the past five years, ROA is the return on assets, and ROE is the return on equity.

\begin{tabular}{|c|c|c|c|c|c|c|c|c|}
\hline & \multicolumn{2}{|c|}{ Turnover } & \multicolumn{2}{|c|}{ StdTurnover } & \multicolumn{2}{|c|}{ ROA } & \multicolumn{2}{|c|}{ ROE } \\
\hline & Good & Comp & Good & Comp & Good & Comp & Good & Comp \\
\hline $\mathrm{N}$ & 522 & 4674 & 522 & 4674 & 522 & 4674 & 522 & 4674 \\
\hline Mean & 0.0846 & 0.1045 & 0.0536 & 0.0624 & 11.5833 & 8.3047 & 11.7955 & 7.1249 \\
\hline Std & 0.0960 & 0.1189 & 0.0531 & 0.0647 & 8.3102 & 7.3445 & 11.0309 & 13.9302 \\
\hline$t$-stat & \multicolumn{2}{|c|}{$4.36^{* * *}$} & \multicolumn{2}{|c|}{$3.49^{* *}$} & \multicolumn{2}{|c|}{$-8.64^{* * *}$} & \multicolumn{2}{|c|}{$-8.91^{* * *}$} \\
\hline
\end{tabular}

*** and ${ }^{* * *}$ denote the one-tailed significance levels of $5 \%, 1 \%$, and $0.1 \%$, respectively.

Table 3 presents the empirical results of the relationship between CSR and employee turnover for Equations (1) and (2). The results show a negative correlation between CSR in the previous period and the employee turnover in the current period and the standard deviation of employee turnover. The employees of the companies that are awarded the CommonWealth Corporate Citizen Award have a more positive view of the companies and higher employee satisfaction, so the employee turnover is lower and the fluctuation of the employee turnover is more moderate. As for the control variables, total assets, years of establishment, and employee turnover are negatively correlated, perhaps because the companies that have been established for a longer period have relatively comprehensive welfare systems and lower turnover.

Table 3. Results for testing the relation between CSR and employee turnover. This table presents the results for testing the relation between CSR and employee turnover, i.e., to examine our first hypothesis. The regression models are: Turnover $_{\mathrm{i}, \mathrm{t}}=\alpha_{0}+\alpha_{1} \mathrm{CSR}_{\mathrm{i}, \mathrm{t}-1}+\alpha_{2} \operatorname{Size}_{\mathrm{i}, \mathrm{t}}+\alpha_{3}$ Age $_{\mathrm{i}, \mathrm{t}}+$ $\alpha_{4}$ IndusDum $_{\mathrm{i}, \mathrm{t}}+\alpha_{5}$ YearDum $_{\mathrm{i}, \mathrm{t}}+\varepsilon_{\mathrm{i}, \mathrm{t}}$, (1) and StdTurnover $\mathrm{i}_{\mathrm{t}, \mathrm{t}}=\alpha_{0}+\alpha_{1}$ CSR $_{\mathrm{i}, \mathrm{t}-1}+\alpha_{2}$ Size $_{\mathrm{i}, \mathrm{t}}+$ $\alpha_{3}$ Age $_{\mathrm{i}, \mathrm{t}}+\alpha_{4}$ IndusDum $_{\mathrm{i}, \mathrm{t}}+\alpha_{5}$ YearDum $_{\mathrm{i}, \mathrm{t}}+\varepsilon_{\mathrm{i}, \mathrm{t}}$ (2) where Turnover $_{\mathrm{i}, \mathrm{t}}$ is the employee turnover of company $i$ in the current period (period $t$ ); StdTurnover $_{i, t}$ is the standard deviation of employee turnover of company $i$ from the previous period to the current period (i.e., period $t$ ); $\mathrm{CSR}_{\mathrm{i}, \mathrm{t}-\mathrm{1}}$ is the dummy variable and equals one if the company is a CSR company in the previous period and zero otherwise; Size $_{i, t}$ is the size of company $i$ in the current period, measured by the logarithm of assets; $\mathrm{Age}_{\mathrm{i}, \mathrm{t}}$ is the number of years from the establishment of company $\mathrm{i}$ to the current period; IndusDum $i, t$ is the industry dummy variable; YearDum ${ }_{i, t}$ is the year dummy variable and $\varepsilon_{i, t}$ is the residual term.

\begin{tabular}{|c|c|c|}
\hline $\begin{array}{c}\text { Model } \\
\text { Variable }\end{array}$ & $\begin{array}{c}\text { (1) } \\
\text { Turnover }\end{array}$ & $\begin{array}{c}\text { (2) } \\
\text { StdTurnover }\end{array}$ \\
\hline Intercept & $\begin{array}{c}0.2881 \\
(12.31)^{* * *}\end{array}$ & $\begin{array}{c}0.1021 \\
(8.08)^{* * *}\end{array}$ \\
\hline $\mathrm{CSR}_{\mathrm{t}-1}$ & $\begin{array}{c}-0.0147 \\
(-2.366) * *\end{array}$ & $\begin{array}{l}-0.0069 \\
(-2.33) *\end{array}$ \\
\hline Age & $\begin{array}{c}-0.0009 \\
(-8.88)^{* * * *}\end{array}$ & $\begin{array}{c}-0.0003 \\
(-4.76)^{* * *}\end{array}$ \\
\hline Size & $\begin{array}{c}-0.0064 \\
(-4.57)^{* * *}\end{array}$ & $\begin{array}{l}-0.0019 \\
(-2.53)^{* *}\end{array}$ \\
\hline$F$-stat & $28.27^{* * *}$ & $10.2^{* * *}$ \\
\hline Adj-R $R^{2}$ & 0.0305 & 0.0105 \\
\hline $\mathrm{N}$ & 5196 & 5196 \\
\hline
\end{tabular}

In Equations (3) and (4), the empirical results of the impact of employee turnover and turnover criteria on both financial performance measures are presented in Table 4 . The relationship between employee turnover and ROA and ROE is significantly negative, and 
the lower the employee turnover, the better the financial performance of the company. This is consistent with the expectation of hypothesis 2a. If an employee leaves, the company must spend additional costs in recruiting and training employees, and the original human capital must be re-accumulated due to the impairment from the employee's departure. All these negatively affect financial performance. Equation (4) explores the relationship between the stability of employee turnover and financial performance by using the standard deviation of employee turnover. The results also show that the variance of employee turnover is negatively correlated to ROA and ROE. Testing via both the employee turnover and the standard deviation of employee turnover shows that employee satisfaction has a significant impact on the financial performance of the company.

Table 4. Results for testing the relation between employee turnover/employee. Turnover variability and firm performance. This table presents the results for testing the relation between employee turnover/employee turnover variability and firm performance, i.e., to examine our second hypothesis. The regression models are: Fin $_{\mathrm{i}, \mathrm{t}}=\alpha_{0}+\alpha_{1}$ Turnover $_{\mathrm{i}, \mathrm{t}}+\alpha_{2}$ Fin $_{\mathrm{i}, \mathrm{t}-1}+$ $\alpha_{3}$ Age $_{\mathrm{i}, \mathrm{t}}+\alpha_{4}$ Size $_{\mathrm{i}, \mathrm{t}}+\alpha_{5}$ IndusDum $_{\mathrm{i}, \mathrm{t}}+\alpha_{6}$ YearDum $_{\mathrm{i}, \mathrm{t}}+\varepsilon_{\mathrm{i}, \mathrm{t}}$, (3) and Fin i, $_{\mathrm{t}}=\alpha_{0}+\alpha_{1}$ Turnover $_{\mathrm{i}, \mathrm{t}}+$ $\alpha_{2}$ Fin $_{\mathrm{i}, \mathrm{t}-1}+\alpha_{3}$ Age $_{\mathrm{i}, \mathrm{t}}+\alpha_{4}$ Size $_{\mathrm{i}, \mathrm{t}}+\alpha_{5}$ IndusDum $_{\mathrm{i}, \mathrm{t}}+\alpha_{6}$ YearDum $_{\mathrm{i}, \mathrm{t}}+\varepsilon_{\mathrm{i}, \mathrm{t}},(4)$ where Fin $_{\mathrm{i}, \mathrm{t}}$ is the return on assets, or return on equity of company $i$ in the current period; Turnover $r_{i \cdot t}$ is the employment turnover of company $i$ in the current period, StdTurnover $r_{i, t}$ is the standard deviation of the employee turnover of company $i$ from the previous period to the current period. As for the control variables: Fin $_{\mathrm{i}, \mathrm{t}-1}$ is the return on assets, growth in sales, return on sales, and growth rate on sales per person company $i$ in the previous period; Age $_{i, t}$ is the number of years from the establishment of company $i$ to the current period; Size $_{i, t}$ is the size of company $i$ in the current period, measured by the logarithm of assets; IndusDum ${ }_{i, t}$ is the industry dummy variable; YearDum ${ }_{i, t}$ is the year dummy variable and $\varepsilon_{i, t}$ is the residual term.

\begin{tabular}{ccccc}
\hline \multirow{2}{*}{$\begin{array}{c}\text { Model } \\
\text { Variable }\end{array}$} & \multicolumn{2}{c}{ (3) } & \multicolumn{2}{c}{ (4) } \\
\cline { 2 - 5 } & ROA $_{\mathbf{t}}$ & ROE $_{\mathbf{t}}$ & ROA $_{\mathbf{t}}$ & $\mathbf{R O E}_{\mathbf{t}}$ \\
\hline \multirow{2}{*}{ Intercept } & 1.4422 & -0.7129 & 1.0820 & -2.3168 \\
& $(1.52)$ & $(-0.31)$ & $(1.14)$ & $(-1.01)$ \\
Turnover & -2.1794 & -6.5096 & - & - \\
& $(-3.97)^{* * *}$ & $(-4.80)^{* * *}$ & - & - \\
StdTurnover & - & - & -2.4388 & -3.2907 \\
& - & - & $(-2.38)^{* *}$ & $(-1.31)$ \\
Fin & 0.7554 & 0.5354 & 0.7541 & $0.5375^{* * *}$ \\
& $(84.91)^{* * *}$ & $(46.25)^{* * *}$ & $(84.07)^{* * *}$ & $(46.25)^{* * *}$ \\
Age & -0.0086 & 0.0024 & -0.0074 & 0.0074 \\
& $(-2.10)^{*}$ & $(0.24)$ & $(-1.82)^{*}$ & $(0.75)$ \\
Size & -0.0274 & 0.0101 & -0.0178 & 0.0482 \\
& $(-0.5)$ & $(0.07)$ & $(-0.33)$ & $(0.36)$ \\
\hline F-stat & $1209.33^{* * *}$ & $330.79 * * *$ & $1205.54 * * *$ & $326.39 * * *$ \\
Adj-R & 0.6195 & 0.3077 & 0.6188 & 0.3048 \\
$\mathrm{~N}$ & 5196 & 5196 & 5196 & 5196 \\
\hline
\end{tabular}

The $t$-statistics are in the parentheses. ${ }^{*}, * *$, and ${ }^{* * *}$ denote the one-tailed significance levels of $5 \%, 1 \%$, and $0.1 \%$, respectively.

Various studies use the methodology of Baron and Kenny [79] to examine the effect of mediation. Baron and Kenny [79] first propose that regression analysis should be separately performed on the effect of independent variables on mediation variables, the effect of mediation variables on dependent variables, and the effect of independent variables on dependent variables. The mediation variable is then added to the regression equation of "the effect of independent variables on dependent variables." If the effect of the independent variable becomes zero after the mediation variable is added, the variable is fully mediated, and if the independent variables are still significant but smaller than the effect before the addition of the mediation variable, then the mediation variable is partially mediated. Later, some scholars further suggest other views. Some scholars point out that the indirect 
effect should be verified directly instead of using the weakened direct effect as evidence. Therefore, this gives birth to the Sobel test, Aroian test, and Goodman test.

This study first explores if the concept of Baron and Kenny [79] is consistent with the situation concerning "the weakened effect of CSR on financial performance after the mediation variable of employee turnover is added." According to the results in Table 5, whether ROA or ROE is used as the financial performance variable, the regression coefficient and $p$-value of CSR tend to weaken after employee turnover is added, which is consistent with the statement of Baron and Kenny [79] that employee turnover has a partial mediation effect. Similarly, this study also tests the standard deviation of employee turnover, and after the standard deviation of employee turnover is added, the impact of CSR on financial performance is also weakened. Therefore, this shows that there is a partial mediation effect of both employee turnover and the standard deviation of employee turnover.

Table 5. Results for testing the relation between CSR and financial performance. This table presents the results for testing the relation between CSR and financial performance, i.e., to examine the third hypothesis. The regression models are: $\operatorname{Fin}_{\mathrm{i}, \mathrm{t}}=\alpha_{0}+\alpha_{1} \operatorname{CSR}_{\mathrm{i}, \mathrm{t}-1}+\alpha_{2} \operatorname{Fin}_{\mathrm{i}, \mathrm{t}-1}+\alpha_{3}$ Age $_{\mathrm{i}, \mathrm{t}}+$ $\alpha_{4}$ Size $_{\mathrm{i}, \mathrm{t}}+\alpha_{5}$ IndusDum $_{\mathrm{i}, \mathrm{t}}+\alpha_{6}$ YearDum $_{\mathrm{i}, \mathrm{t}}+\varepsilon_{\mathrm{i}, \mathrm{t}}$, (5) Fin $_{\mathrm{i}, \mathrm{t}}=\alpha_{0}+\alpha_{1}$ Turnover $_{\mathrm{i}, \mathrm{t}}+\alpha_{2}$ CSR $_{\mathrm{i}, \mathrm{t}-1}+$ $\alpha_{3}$ Fin $_{\mathrm{i}, \mathrm{t}-1}+\alpha_{4}$ Age $_{\mathrm{i}, \mathrm{t}}+\alpha_{5}$ Size $_{\mathrm{i}, \mathrm{t}}+\alpha_{6}$ IndusDum $_{\mathrm{i}, \mathrm{t}}+\alpha_{7}$ YearDum $_{\mathrm{i}, \mathrm{t}}+\varepsilon_{\mathrm{i}, \mathrm{t}}$, (6) and Fin $_{\mathrm{i}, \mathrm{t}}=$ $\alpha_{0}+\alpha_{1}$ StdTurnover $_{\mathrm{i}, \mathrm{t}}+\alpha_{2}$ CSR $_{\mathrm{i}, \mathrm{t}-1}+\alpha_{3}$ Fin $_{\mathrm{i}, \mathrm{t}-1}+\alpha_{4}$ Age $_{\mathrm{i}, \mathrm{t}}+\alpha_{5}$ Size $_{\mathrm{i}, \mathrm{t}}+\alpha_{6}$ IndusDum $_{\mathrm{i}, \mathrm{t}}+$ $\alpha_{7}$ YearDum $_{i, t}+\varepsilon_{i, t},(7)$ where Fin $i, t$ includes return on assets $\left(\operatorname{ROA}_{i, t}\right)$ and return on equity $\left(\operatorname{ROE}_{i, t}\right)$ of the company $\mathrm{i}$ in the current period; $\mathrm{CSR}_{\mathrm{i}, \mathrm{t}-1}$ is the dummy variable and equals one if the company is a CSR company in the previous period and zero otherwise. As for the control variables, Fin $_{\mathrm{i}, \mathrm{t}-\mathrm{1}}$ is corresponding financial performance of company $i$ in the previous period, i.e., either $\mathrm{ROA}_{\mathrm{i}, \mathrm{t}-\mathrm{i}}$ or $\mathrm{ROE}_{\mathrm{i}, \mathrm{t}-1} ; \mathrm{Age}_{\mathrm{i}, \mathrm{t}}$ is the number of years from the establishment of company $\mathrm{i}$ to the current period; Size $_{i, t}$ is the size of company $i$ in the current period, measured by the logarithm of assets; IndusDum is the industry dummy variable; YearDum is the year dummy variable and $\varepsilon_{i, t}$ is the residual term.

\begin{tabular}{|c|c|c|c|c|c|c|}
\hline \multirow{2}{*}{$\begin{array}{c}\text { Model } \\
\text { Variable }\end{array}$} & \multicolumn{2}{|c|}{ (5) } & \multicolumn{2}{|c|}{ (6) } & \multicolumn{2}{|c|}{ (7) } \\
\hline & $\mathrm{ROA}_{\mathbf{t}}$ & $\mathrm{ROE}_{\mathrm{t}}$ & $\mathrm{ROA}_{t}$ & $\mathrm{ROE}_{\mathrm{t}}$ & $\mathrm{ROA}_{t}$ & $\mathrm{ROE}_{\mathrm{t}}$ \\
\hline \multirow{2}{*}{ Intercept } & 1.4015 & -1.4524 & 2.0398 & 0.4230 & 1.7084 & -1.1219 \\
\hline & $(1.48)$ & $(-0.63)$ & $(2.12) *$ & $(0.18)$ & $(1.78)^{*}$ & $(-0.49)$ \\
\hline \multirow{2}{*}{$\mathrm{CSR}_{\mathrm{t}-1}$} & 0.8704 & 2.0204 & 0.8443 & 1.9429 & 0.8646 & 2.0052 \\
\hline & $(3.94)^{* * *}$ & $(3.74) * *$ & $(3.83)^{* * *}$ & $(3.60)^{* *}$ & $(3.92) * * *$ & $(3.71)^{* *}$ \\
\hline \multirow{2}{*}{ Turnover } & - & - & -2.1152 & -6.3606 & - & - \\
\hline & - & - & $(-3.86)^{* * *}$ & $(-4.70)^{* * *}$ & - & - \\
\hline \multirow{2}{*}{ StdTurnover } & - & - & - & - & -2.3937 & -3.0756 \\
\hline & - & - & - & - & $(-2.34) *$ & $(-1.22)$ \\
\hline \multirow{2}{*}{$\operatorname{Fin}_{\mathrm{t}-1}$} & 0.7508 & 0.5341 & 0.7496 & 0.5310 & 0.7482 & 0.5329 \\
\hline & $(83.25)^{* * *}$ & $(45.91)^{* * *}$ & $(83.18)^{* * *}$ & $(45.66)^{* * *}$ & $(82.37)^{* * *}$ & $(45.65)^{* * *}$ \\
\hline \multirow{2}{*}{ Age } & -0.0065 & 0.0095 & 0.0085 & 0.0037 & -0.0073 & 0.0087 \\
\hline & $(-1.60)$ & $(0.97)$ & $(-2.07) *$ & $(0.37)$ & $(-1.80) *$ & $(0.88)$ \\
\hline \multirow{2}{*}{ Size } & -0.0490 & -0.0271 & -0.0630 & -0.0681 & -0.0547 & -0.0331 \\
\hline & $(-0.88)$ & $(-0.20)$ & $(-1.13)^{* *}$ & $(-0.50)$ & $(-0.98)$ & $(-0.24)^{* * *}$ \\
\hline F-stat & $1209.24^{* * *}$ & $328.91^{* * *}$ & $1062.78^{* * *}$ & $291.72 * * *$ & $1059.68^{* * *}$ & $288.01^{* * *}$ \\
\hline Adj-R $R^{2}$ & 0.6195 & 0.3064 & 0.6205 & 0.3092 & 0.6198 & 0.3525 \\
\hline $\mathrm{N}$ & 5196 & 5196 & 5196 & 5196 & 5196 & 5196 \\
\hline
\end{tabular}

${ }^{*},{ }^{* *}$, and ${ }^{* * *}$ denote the one-tailed significance levels of $5 \%, 1 \%$, and $0.1 \%$, respectively. The $t$-statistics are in the parentheses.

In this study, the Sobel test, Aroian test, and Goodman test are also used to examine the mediation effects, with the results shown in Table 6. Panel A shows that both ROA and ROE in the Sobel test, Aroian test, and Goodman test are significant. Therefore, CSR has an impact on financial performance through the mediation of employee turnover, and employee turnover has a mediation effect indeed. Panel B uses the standard deviation of employee turnover as the mediation variable for testing, and the results show that ROA used as 
an indicator of financial performance is also significant. Thus, the employee turnover variability also has a mediation effect on the impact of CSR on financial performance.

Table 6. Sobel test results.

\begin{tabular}{|c|c|c|c|}
\hline \multicolumn{4}{|c|}{ Panel A Dependent Variable (Mediator: Turnover) } \\
\hline & & $t$-Statistic & $p$-Value \\
\hline \multirow{3}{*}{ ROA } & Sobel test & $2.2115 *$ & 0.0135 \\
\hline & Aroian test & $2.1647 *$ & 0.0152 \\
\hline & Goodman test & $2.2615^{*}$ & 0.0119 \\
\hline \multirow{3}{*}{ ROE } & \multirow{3}{*}{$\begin{array}{l}\text { Sobel testAroian } \\
\text { testGoodman test }\end{array}$} & $2.3286^{* *}$ & 0.0099 \\
\hline & & $2.2910 *$ & 0.0110 \\
\hline & & $2.3682 * *$ & 0.0090 \\
\hline \multicolumn{4}{|c|}{ Panel B Dependent Variable (Mediator:StdTurnover) } \\
\hline & & $t$-Statistic & $p$-Value \\
\hline \multirow{3}{*}{ ROA } & Sobel test & $1.6651 *$ & 0.0480 \\
\hline & Aroian test & 1.5947 & 0.0554 \\
\hline & Goodman test & $1.7456^{*}$ & 0.0404 \\
\hline \multirow{3}{*}{ ROE } & Sobel test & 1.1392 & 0.1273 \\
\hline & Aroian test & 1.0669 & 0.1430 \\
\hline & Goodman test & 1.2285 & 0.1096 \\
\hline
\end{tabular}

\section{Discussion}

Extant literature focuses on the relationship between two variables, CSR achievement and financial measure. Intuitively, corporate expenditures on CSR would help increase the firm value. There may be two reasons that sound CSR performance may result in better financial performance. First, CSR performance may induce higher stock prices as a result of the enhanced market perceptions regarding the firm. Second, based on the stakeholder theory, CSR achievements add to the firm value of corporate stakeholders as reflected in earnings achieved either through increased revenues, greater customer satisfaction, reduced production costs, higher supplier/employee satisfaction, lower capital costs resulted from optimistic banks or investor attitudes, or in combination. However, the prior literature does not clarify whether and the extent to which certain mediation channels may affect the significance of the impact of CSR on the stakeholders on corporate financial performance. This study, in contrast, focuses on how and through which avenue CSR conducts would result in sound financial outcomes.

The findings suggest that employee turnover has a mediation effect on the relationship between CSR and financial performance and that CSR affects the financial performance of a company through the resulted change in employee satisfaction, which is measured by employee turnover in this study. The stakeholder theory has a far-reaching influence in the field of CSR research [6], and Lin et al. [16] documented that stakeholder requirements in environmentally sensitive industries are more stringent and intense than those in environmentally insensitive industries. The companies in environmentally sensitive industries that engage in CSR activities that meet stakeholder requirements may gain reputation, recognition, and resources controlled by these stakeholders, and therefore, the company will gain an advantage and improve its financial performance.

\section{Conclusions, Implications, Limitations and Recommendations}

Based on the stakeholder theory, this paper focuses on employee satisfaction, and extensively explores the relationships among CSR achievements, employee turnover, and corporate financial performance. Although previous studies have suggested that CSR positively impacts labor relations, there is no empirical study that verifies the relationship between the two variables. Specifically, we compared the socially responsible companies 
with the control group ones and adopted employee turnover and the standard deviation of employee turnover as indicators of employee satisfaction to examine the mediation effect of CSR on financial performance. The results show that both return on assets and return on equity of socially responsible firms are significantly greater than those of the companies in the control group. Furthermore, the employee turnover is significantly lower for the former firms than that of the control observations. The results support the notion that the employee satisfaction serves as a mediation factor of the impact of CSR accomplishments on financial soundness.

Our findings provide the references as follows: (1) for the company's management team, its engaging in social responsibility activities helps reduce both employee turnover rate and employee turnover variability. A lower employee turnover and employee turnover variability in turn will reduce inefficiency and ineffectiveness during the production process. Specifically, the departures of potentially productive workers cause a loss because the decrease in product value that could have been added by the departing employees would exceed the decrease in wage and salary expenses. Furthermore, there may be significant costs associated with the recruitment, training, and acclimatization of new employees. In a bust, although the policy of salary reduction and unpaid leave is an expedient way to cope with the short-term deterioration of the economy, compared with the negative impact of layoffs on society, the social planners should still prudently take into account the roles that may be played by the potential related requirements, (2) for general investors or institutional investors that intend to engage in socially responsible investment, understanding the difference in the nature of employee turnover and financial performance between socially responsible companies and control group observations also help long-term investors create or capture more excess returns.

Future studies in the related area may aim at a broader investigation of (1) the roles the (other) potential mediators play in the effectiveness of CSR efforts on enhancing the shareholders' value, and (2) the extent to which the best practice of CSR conduct may be firm-specific. Finally, one non-trivial limitation of this study is the unavailability of detailed data and information regarding the historical CSR accomplishments of the firms for Taiwanese companies. The only source that provides such measurements is the CommonWealth Magazine, from which we retrieved the list of firms that received CSR awards. The magazine derives the award-winning list by a multidimensional weighted scoring measurement based upon the ratings by its committees of invited experts, the magazine insists on not providing any detailed evaluation results. Falling short in obtaining the continuous CSR measures, we categorized the sample into two groups, the companies that received the CSR awards and the ones that failed to receive such awards, adopting a binary instead of a continuous variable to characterize the CSR achievements. Future work in this area may entail extensions with more comprehensive data pertaining to CSR achievements.

\section{Note Materials}

1. In the last three years, the Ministry of Corporate Affairs in India implemented the Companies Act, 2013, which requires organizations to spend $2 \%$ of their average net profit on CSR activities.

2. The macroscopic infers that "good employee reactions" will bring better "overall performance" of the company after a company improves its relations with its employees.

3. Other scholars use the corporate citizenship indicators in the benchmark corporate reputation survey published by the CommonWealth Magazine as the basis for CSR measurement.

4. Take the 2010 CommonWealth Corporate Citizenship Awards as an example: The 2010 Corporate Citizenship Survey is conducted by CommonWealth Magazine in reference to the United Nations' guidelines, the OECD, and the Dow Jones Sustainability Index. The survey is divided into three stages. The first stage is the preliminary selection of companies that have generated profits for three consecutive years from the public 
companies (including listed, over-the-counter, and emerging companies) supervised by the Financial Supervisory Commission as well as foreign companies in Taiwan selected from the CommonWealth Top 1000 Survey and recommended by scholars and experts. In 2010, there were a total of 2072 publicly listed companies and 151 foreign companies. During the second-stage selection, the editorial department of CommonWealth Magazine rates the responses from the companies. Finally, a 12member panel of judges conducts the third stage of final selection with credibility and social prestige to select the CommonWealth Top 50 Corporate Citizens out of 118 companies (including 54 large companies, 27 medium-sized companies, and 36 foreign companies, with a capital size of TWD 10 billion as the classified threshold of Taiwanese companies.

5. This also explains why the Taiwan Employment 99 Index of the Taiwan Stock Exchange can define whether a company is fulfilling its social responsibility based solely on the number of employees it employs, because unemployment in a full employment environment has a comprehensive impact on society. Therefore, the companies that hire a large number of employees contribute to a certain extent to social stability.

6. Take the Fubon Taiwan CSR Fund for example. This type of fund requires a certain percentage of shareholding in socially responsible enterprises. For example, such a fund requires that the weighting on its investment in "socially responsible stocks" should not be lower than $60 \%$ of the fund's net asset value.

7. We thank the anonymous academic editor for his suggestion to add a table that summarizes the main literature contribution.

\begin{tabular}{|c|c|c|}
\hline Reference & Related Fields & Main Findings and Implications \\
\hline $\begin{array}{l}\text { Wood and } \\
\text { Jones [10] }\end{array}$ & Stakeholder Theory & $\begin{array}{l}\text { Stakeholder theory is the key to understanding } \\
\text { the structure and aspects of the relationship } \\
\text { between businesses and society because it helps } \\
\text { explain the relationship among various business } \\
\text { performance indicators. The stakeholder theory } \\
\text { recognizes that stakeholders, namely, } \\
\text { shareholders, employees, customers, } \\
\text { competitors, communities, upstream and } \\
\text { downstream suppliers, and governments, are the } \\
\text { recipients of a company's actions and outcomes } \\
\text { and the source of judgments regarding how well } \\
\text { the company is meeting expectations. }\end{array}$ \\
\hline $\begin{array}{l}\text { McWilliams and } \\
\text { Siegel [11] }\end{array}$ & CSR Definitions & $\begin{array}{c}\text { McWilliams and Siegel [11] defined CSR as } \\
\text { actions that appear to further some social good } \\
\text { beyond the firm's interests and that which is } \\
\text { required by law. }\end{array}$ \\
\hline Carrol [12] & CSR Definitions & $\begin{array}{l}\text { Carrol [12] described corporate social } \\
\text { performance as the three-dimensional } \\
\text { integration of CSR, corporate social } \\
\text { responsiveness, and social issues. }\end{array}$ \\
\hline $\begin{array}{l}\text { Matten and } \\
\text { Moon [13] }\end{array}$ & CSR Definitions & $\begin{array}{l}\text { Matten and Moon [13] defined corporate social } \\
\text { performance a synonym of CSR, corporate social } \\
\text { responsiveness, or any other interaction between } \\
\text { business and social environment. }\end{array}$ \\
\hline Frederick [14] & CSR Definitions & $\begin{array}{c}\text { Frederick [14] explored CSR as a requirement for } \\
\text { businesses to monitor the operation of an } \\
\text { economic system to meet public expectations. }\end{array}$ \\
\hline
\end{tabular}




\begin{tabular}{|c|c|c|}
\hline Kim et al. [1] & $\begin{array}{l}\text { CSR and Financial } \\
\text { Performance }\end{array}$ & $\begin{array}{l}\text { Kim et al. [1] showed that the assurance of CSR } \\
\text { reports will reduce firms' financial costs by } \\
\text { lowering the discount rate for investors, which } \\
\text { will in turn improve the financial outcomes of } \\
\text { the firms. }\end{array}$ \\
\hline $\begin{array}{l}\text { Griffin and } \\
\text { Mahon [3] }\end{array}$ & $\begin{array}{l}\text { CSR and Financial } \\
\text { Performance }\end{array}$ & $\begin{array}{l}\text { Griffin and Mahon [3] summarized } 51 \text { previous } \\
\text { studies and conclude that the five most } \\
\text { commonly measured variables in past studies } \\
\text { are: size, return on assets, return on equity, asset } \\
\text { age (fixed net assets / gross fixed assets), and } \\
\text { five-year return on sales. }\end{array}$ \\
\hline $\begin{array}{l}\text { McWilliams and } \\
\text { Siegel [11] }\end{array}$ & $\begin{array}{l}\text { CSR and Financial } \\
\text { Performance }\end{array}$ & $\begin{array}{l}\text { McWilliams and Siegel [11] assumed that there } \\
\text { are two firms that produce identical goods, } \\
\text { except one company adds a social characteristic } \\
\text { to its product. They show that, in equilibrium, } \\
\text { both will be equally profitable. }\end{array}$ \\
\hline Cho et al. [21] & $\begin{array}{l}\text { CSR and Financial } \\
\text { Performance }\end{array}$ & $\begin{array}{l}\text { Cho et al. [21] collected } 191 \text { sample firms listed } \\
\text { on the Korea Exchange (KEJI) and found that } \\
\text { CSR has a partial positive correlation with a } \\
\text { firm's financial performance proxied by return } \\
\text { on assets and its firm value measured using } \\
\text { Tobin's Q. }\end{array}$ \\
\hline $\begin{array}{l}\text { Uadiale and } \\
\text { Fagbemi [22] }\end{array}$ & $\begin{array}{l}\text { CSR and Financial } \\
\text { Performance }\end{array}$ & $\begin{array}{l}\text { Uadiale and Fagbemi [22] formed a sample of } 40 \\
\text { audited financial statements of listed companies } \\
\text { in Nigeria and found that CSR has a positive and } \\
\text { significant influence on ROE and ROA. }\end{array}$ \\
\hline $\begin{array}{l}\text { Margolis and } \\
\text { Walsh [24] }\end{array}$ & $\begin{array}{l}\text { CSR and Financial } \\
\text { Performance }\end{array}$ & $\begin{array}{c}\text { Margolis and Walsh [24] reviewed } 18 \text { papers in } \\
\text { the previous CSR literature and showed that } \\
\text { only } 53 \% \text { of these papers document a positive } \\
\text { correlation between CSR and financial } \\
\text { performance. }\end{array}$ \\
\hline Cherian et al. [25] & $\begin{array}{l}\text { CSR and Financial } \\
\text { Performance }\end{array}$ & $\begin{array}{c}\text { Cherian et al. [25] used secondary data from } 50 \\
\text { Indian manufacturing firms from } 2011 \text { to } 2017 \\
\text { and found a negative impact on companies from } \\
\text { the disclosure requirement to comply with laws } \\
\text { and regulations. }\end{array}$ \\
\hline Lin et al. [16] & $\begin{array}{l}\text { CSR, Financial } \\
\text { Performance, and } \\
\text { Mediation Effects }\end{array}$ & $\begin{array}{l}\text { Lin et al. [16] showed that intellectual capital has } \\
\text { a mediation effect on the relationship between } \\
\text { CSR and financial performance, while the } \\
\text { industry category moderates the direct impact of } \\
\text { CSR on financial performance. }\end{array}$ \\
\hline $\begin{array}{l}\text { Carmeli, Gilat, and } \\
\text { Waldman [46] }\end{array}$ & $\begin{array}{l}\text { CSR, Employees and } \\
\text { Organization }\end{array}$ & $\begin{array}{l}\text { Carmeli, Gilat, and Waldman [46] surveyed } \\
\text { employees and supervisors at four electronics } \\
\text { and media industry companies and showed that } \\
\text { CSR leads to organizational recognition. }\end{array}$ \\
\hline Jones [41] & $\begin{array}{l}\text { CSR, Employees and } \\
\text { Organization }\end{array}$ & $\begin{array}{l}\text { Jones [41] found that employees' attitudes } \\
\text { regarding a volunteerism program are positively } \\
\text { correlated with organizational pride and } \\
\text { identification. }\end{array}$ \\
\hline Koys [48] & $\begin{array}{l}\text { Employees and } \\
\text { Financial Performance }\end{array}$ & $\begin{array}{l}\text { Koys [48] showed that employee satisfaction, } \\
\text { organizational citizenship behavior, and } \\
\text { employee turnover in the previous period } \\
\text { correlate to the corporate profitability in the next } \\
\text { period. }\end{array}$ \\
\hline
\end{tabular}




\begin{tabular}{|c|c|c|}
\hline Edmans [51] & $\begin{array}{l}\text { Employees and } \\
\text { Financial Performance }\end{array}$ & $\begin{array}{c}\text { Edmans [51] adopted the annual survey data of } \\
\text { the "100 Best Companies to Work For in } \\
\text { America" as an indicator of employee } \\
\text { satisfaction, and showed that these "Best } \\
\text { Companies" have annual stock price returns that } \\
\text { beat the market by two to three percent from } \\
1984 \text { to } 2009 \text {. }\end{array}$ \\
\hline $\begin{array}{c}\text { Ton and } \\
\text { Huckman [56] }\end{array}$ & $\begin{array}{l}\text { Employees and } \\
\text { Financial Performance }\end{array}$ & $\begin{array}{l}\text { Ton and Huckman [56] analyzed employee } \\
\text { turnover of major retail chains in the U.S. and } \\
\text { found that for this industry employee turnover } \\
\text { is linked to the decline of corporate performance. }\end{array}$ \\
\hline Grennan [57] & $\begin{array}{l}\text { Employees and } \\
\text { Financial Performance }\end{array}$ & $\begin{array}{c}\text { Grennan [57] found that corporate culture, } \\
\text { constructed by the employee reviews of the firm, } \\
\text { is positively correlated with long-term firm } \\
\text { value. }\end{array}$ \\
\hline Huang et al. [60] & $\begin{array}{l}\text { Employees and } \\
\text { Financial Performance }\end{array}$ & $\begin{array}{l}\text { Huang et al. [60] explored the impact of } \\
\text { employee satisfaction on firm value and found } \\
\text { that the organizational form affects the } \\
\text { employees' perceptions of the company and } \\
\text { leadership and then further affects corporate } \\
\text { performance. }\end{array}$ \\
\hline $\begin{array}{l}\text { Yoo, Choi, and } \\
\text { Chon [62] }\end{array}$ & $\begin{array}{l}\text { Employees and } \\
\text { Financial Performance }\end{array}$ & $\begin{array}{l}\text { Yoo, Choi, and Chon [62] suggested that CSR } \\
\text { affects accounting profitability by enhancing } \\
\text { employee commitment. }\end{array}$ \\
\hline
\end{tabular}

8. We thank the anonymous academic editor for his suggestion to add a table to show the hypotheses that are confirmed.

\begin{tabular}{|c|c|c|}
\hline Hypotheses & Predictions & Test Results \\
\hline $\mathrm{H} 1 \mathrm{a}$ & $\begin{array}{l}\text { The firms that focus more on CSR have } \\
\text { significantly lower employee turnovers than the } \\
\text { control firms in the same industry. }\end{array}$ & $\begin{array}{l}\text { Supported } \\
\text { (Table 3) }\end{array}$ \\
\hline $\mathrm{H} 1 \mathrm{~b}$ & $\begin{array}{l}\text { The firms that focus more on CSR have } \\
\text { significantly more stable employee turnovers } \\
\text { than the control firms in the same industry. }\end{array}$ & $\begin{array}{l}\text { Supported } \\
\text { (Table 3) }\end{array}$ \\
\hline $\mathrm{H} 2 \mathrm{a}$ & $\begin{array}{l}\text { The firms with lower employee turnovers } \\
\text { financially outperform the control firms in the } \\
\text { same industry. }\end{array}$ & $\begin{array}{l}\text { Supported } \\
\text { (Table 4) }\end{array}$ \\
\hline $\mathrm{H} 2 \mathrm{~b}$ & $\begin{array}{l}\text { The firms with stable employee turnovers in the } \\
\text { previous period financially outperform the } \\
\text { control firms in the same industry. }\end{array}$ & $\begin{array}{l}\text { Supported } \\
\text { (Table 4) }\end{array}$ \\
\hline $\mathrm{H} 3$ & $\begin{array}{l}\text { When employee turnover serves as the } \\
\text { mediation variable, with a control of industry } \\
\text { characteristics, the impact of CSR on financial } \\
\text { performance becomes significant. }\end{array}$ & $\begin{array}{c}\text { Supported } \\
\text { (Tables } 5 \text { and 6) }\end{array}$ \\
\hline
\end{tabular}

Author Contributions: Conceptualization, H.-W.L. and W.-H.T.; methodology, C.-H.C. and C.-T.H.; software, W.-L.W. and C.-T.H.; validation, W.-L.W. and C.-T.H.; formal analysis, H.-W.L. and W.-H.T.; data curation, W.-L.W. and C.-T.H.; writing-original draft preparation, C.-H.C. and W.-L.W.; writing-review and editing, C.-H.C. and C.-T.H.; visualization, C.-H.C. and W.-L.W.; supervision, W.-H.T.; project administration, H.-W.L. All authors have read and agreed to the published version of the manuscript.

Funding: This research received no external funding. 
Conflicts of Interest: The authors declare no conflict of interest.

\section{References}

1. Kim, J.; Cho, K.; Park, C.K. Does CSR Assurance Affect the Relationship between CSR Performance and Financial Performance? Sustainability 2019, 11, 5682. [CrossRef]

2. Waddock, S.A.; Graves, S.B. The corporate social performance-Financial performance link. Strateg. Manag. J. 1997, 18, 303-319. [CrossRef]

3. Griffin, J.J.; Mahon, J.F. The corporate social performance and corporate financial performance debate: Twenty-five years of incomparable research. Bus. Soc. 1997, 36, 5-31. [CrossRef]

4. Hristov, I.; Appolloni, A.; Chirico, A.; Cheng, W. The role of the environmental dimension in the performance management system: A systematic review and conceptual framework. J. Clean. Prod. 2021, 293, 126075. [CrossRef]

5. Moskowitz, M. Choosing socially responsible stocks. Bus. Soc. 1972, 1, 71-75.

6. Freeman, R.E. Strategic Management: A Stakeholder Approach; Pitman Publishing: Boston, MA, USA, 1984.

7. Bauman, C.W.; Skitka, L.J. Corporate social responsibility as a source of employee satisfaction. Res. Organ. Behav. 2012, 32, 63-86. [CrossRef]

8. Bowen, H.R. Social Responsibilities of the Businessman; Harper \& Row: New York, NY, USA, 1953.

9. Friedman, M. The Social Responsibility of Business Is to Increase Its Profits. In Corporate ethics and Corporate Governance; Springer: Berlin/Heidelberg, Germany, 2007; pp. 173-178. [CrossRef]

10. Wood, D.J.; Jones, E.J. Stakeholder mismatching: A theoretical problem in empirical research on corporate social performance. Int. J. Organ. Anal. 1995, 3, 229-267. [CrossRef]

11. McWilliams, A.; Siegel, D. Corporate social responsibility: A theory of the firm perspective. Acad. Manag. Rev. 2001, 26, 117-127. [CrossRef]

12. Carroll, A.B. Corporate social responsibility: Evolution of a definitional construct. Bus. Soc. 1999, 38, 268-295. [CrossRef]

13. Matten, D.; Moon, J. Corporate social responsibility education in Europe. J. Bus. Ethics 2005, 54, 323-337. [CrossRef]

14. Frederick, W.C. Point of View: Corporate Social Responsibility in the Reagan Era and beyond. Calif. Manag. Rev. 1983, 25, 145-157. [CrossRef]

15. Mirfazli, E. Evaluate corporate social responsibility disclosure at Annual Report Companies in multifarious group of industry members of Jakarta Stock Exchange (JSX), Indonesia. Soc. Responsib. J. 2008, 4, 388-406. [CrossRef]

16. Lin, C.S.; Chang, R.Y.; Dang, V.T. An integrated model to explain how corporate social responsibility affects corporate financial performance. Sustainability 2015, 7, 8292-8311. [CrossRef]

17. Ullman, A.H. Data in search of a theory: A critical examination of the relationships among social performance, social disclosure, and economic performance of us firms. Acad. Manag. Rev. 1985, 10, 540-557.

18. Hillman, A.J.; Keim, G.D. Shareholder value, stakeholder management, and social issues: What's the bottom line? Strateg. Manag. J. 2001, 22, 125-139. [CrossRef]

19. Simpson, W.G.; Kohers, T. The Link Between Corporate Social and Financial Performance: Evidence from the Banking Industry. J. Bus. Ethics 2002, 35, 97-109. [CrossRef]

20. Preston, L.E.; O'Bannon, D.P. The corporate social-financial performance relationship. Bus. Soc. 1997, 36, 419-429. [CrossRef]

21. Cho, S.J.; Chung, C.Y.; Young, J. Study on the Relationship between CSR and Financial Performance. Sustainability 2019, 11, 343. [CrossRef]

22. Uadiale, O.M.; Fagbemi, T.O. Corporate social responsibility and financial performance in developing economies: The Nige-rian experience. J. Econ. Sustain. Dev. 2012, 3, 44-54.

23. Garcia-Castro, R.; Ariño, M.A.; Canela, M.A. Does Social Performance Really Lead to Financial Performance? Accounting for Endogeneity. J. Bus. Ethics 2009, 92, 107-126. [CrossRef]

24. Margolis, J.D.; Walsh, J.P. Misery Loves Companies: Rethinking Social Initiatives by Business. Adm. Sci. Q. 2003, 48, 268. [CrossRef]

25. Cherian, J.; Umar, M.; Thu, P.A.; Nguyen-Trang, T.; Sial, M.S.; Khuong, N.V. Does Corporate Social Responsibility Affect the Financial Performance of the Manufacturing Sector? Evidence from an Emerging Economy. Sustainability 2019, $11,1182$. [CrossRef]

26. Aupperle, K.E.; Carroll, A.B.; Hatfield, J.D. An empirical examination of the relationship between corporate social responsibility and profitability. Acad. Manag. J. 1985, 28, 446-463.

27. Russo, M.V.; Fouts, P.A. A resource-based perspective on corporate environmental performance and profitability. Acad. Manag. J. 1997, 40, 534-559.

28. Schuler, D.A.; Cording, M. A Corporate Social Performance-Corporate Financial Performance Behavioral Model for Consumers. Acad. Manag. Rev. 2006, 31, 540-558. [CrossRef]

29. Surroca, J.; Tribó, J.A.; Waddock, S. Corporate responsibility and financial performance: The role of intangible resources. Strateg. Manag. J. 2010, 31, 463-490. [CrossRef]

30. Yasin, R.; Namoco, S.O.; Jauhar, J.; Abdul Rahim, N.F.; Zia, N.U. Responsible leadership an obstacle for turnover intention. Soc. Responsib. J. 2020, in press. [CrossRef]

31. Porter, E.M. On Competition; Harvard Business School Press: Boston, MA, USA, 2008. 
32. Aguilera, R.V.; Rupp, D.E.; Williams, C.A.; Ganapathi, J. Putting the S back in corporate social responsibility: A multilevel theory of social change in organizations. Acad. Manag. Rev. 2007, 32, 836-863. [CrossRef]

33. Aguinis, H.; Glavas, A. What we know and don't know about corporate social responsibility: A review and research agenda. J. Manag. 2012, 38, 932-968. [CrossRef]

34. Rowley, T.; Berman, S. A Brand New Brand of Corporate Social Performance. Bus. Soc. 2000, 39, 397-418. [CrossRef]

35. Wood, D.J. Measuring Corporate Social Performance: A Review. Int. J. Manag. Rev. 2010, 12, 50-84. [CrossRef]

36. Graves, S.B.; Waddock, S.A. Institutional owners and corporate social performance. Acad. Manag. J. 1994, 37, $1034-1046$.

37. Sen, S.; Bhattacharya, C.B. Does Doing Good Always Lead to Doing Better? Consumer Reactions to Corporate Social Responsibility. J. Mark. Res. 2001, 38, 225-243. [CrossRef]

38. Brammer, S.; Millington, A.; Rayton, B. The contribution of corporate social responsibility to organizational commitment. Int. J. Hum. Resour. Manag. 2007, 18, 1701-1719. [CrossRef]

39. Dutton, J.E.; Dukerich, J.M. Keeping an eye on the mirror: Image and identity in organizational adaptation. Acad. Manag. J. 1991, 34, 517-554.

40. Ellemers, N.; Kingma, L.; van de Burgt, J.; Barreto, M. Corporate social responsibility as a source of organizational morality, employee commitment and satisfaction. J. Moral. Organ. Psychol. 2011, 1, 97-124.

41. Jones, D.A. Does serving the community also serve the company? Using organizational identification and social exchange theories to understand employee responses to a volunteerism programme. J. Occup. Organ. Psychol. 2010, 83, 857-878. [CrossRef]

42. Lin, C.P.; Lyau, N.M.; Tsai, Y.H.; Chen, W.Y.; Chiu, C.K. Modeling corporate citizenship and its relationship with organizational citizenship behaviors. J. Bus. Ethics 2010, 95, 357-372. [CrossRef]

43. Peterson, D.K. The Relationship between Perceptions of Corporate Citizenship and Organizational Commitment. Bus. Soc. 2004, 43, 296-319. [CrossRef]

44. Riordan, C.M.; Gatewood, R.D.; Bill, J.B. Corporate Image: Employee Reactions and Implications for Managing Corporate Social Performance. J. Bus. Ethics 1997, 16, 401-412. [CrossRef]

45. Valentine, S.; Fleischman, G. Ethics Programs, Perceived Corporate Social Responsibility and Job Satisfaction. J. Bus. Ethics 2007, 77, 159-172. [CrossRef]

46. Carmeli, A.; Gilat, G.; Waldman, D.A. The Role of Perceived Organizational Performance in Organizational Identification, Adjustment and Job Performance. J. Manag. Stud. 2007, 44, 972-992. [CrossRef]

47. Kaplan, R.S.; Norton, D.P. The Balanced Scorecard: Translating Strategy into Action; Harvard Business School Press: Boston, MA, USA, 1996; p. 322.

48. Koys, D.J. The effects of employee satisfaction, organizational citizenship behavior, and turnover on organizational effectiveness: A unit-level, longitudinal study. Pers. Psychol. 2001, 54, 101-114. [CrossRef]

49. McGregor, D.; Cutcher-Gershenfeld, J. The Human Side of Enterprise; McGraw-Hill: New York, NY, USA, 1960.

50. Zingales, L. In Search of New Foundations. J. Financ. 2000, 55, 1623-1653. [CrossRef]

51. Edmans, A. The Link Between Job Satisfaction and Firm Value, With Implications for Corporate Social Responsibility. Acad. Manag. Perspect. 2012, 26, 1-19. [CrossRef]

52. Bluedorn, A.C. A Unified Model of Turnover from Organizations. Hum. Relat. 1982, 35, 135-153. [CrossRef]

53. Argote, L.; Beckman, S.L.; Epple, D. The Persistence and Transfer of Learning in Industrial Settings. Manag. Sci. 1990, 36, 140-154. [CrossRef]

54. Darmon, R.Y. Identifying sources of turnover costs: A segmental approach. J. Mark. 1990, 54, 46-56. [CrossRef]

55. Palich, L.E.; Hom, P.W.; Griffeth, R.W. Managing in the international context: Testing cultural generality of sources of commitment to multinational enterprises. J. Manag. 1995, 21, 671-690. [CrossRef]

56. Ton, Z.; Huckman, R.S. Managing the Impact of Employee Turnover on Performance: The Role of Process Conformance. Organ. Sci. 2008, 19, 56-68. [CrossRef]

57. Grennan, J. A Corporate Culture Channel: How Increased Shareholder Governance Reduces Firm Value. Available online: https: / / ssrn.com/abstract=2345384 (accessed on 5 September 2021).

58. Mobley, W.H. Employee Turnover: Causes, Consequences and Control Reading; Addison-Wesley: Boston, MA, USA, 1982.

59. Mowday, R.T.; Porter, L.W.; Steers, R. Employee-Organizational Linkages: The Psychology of Commitment, Absenteeism, and Turnover; Academic Press: New York, NY, USA, 1982.

60. Huang, M.; Li, P.; Meschke, F.; Guthrie, J.P. Family firms, employee satisfaction, and corporate performance. J. Corp. Financ. 2015, 34, 108-127. [CrossRef]

61. Schneider, B.; Hanges, P.J.; Smith, D.B.; Salvaggio, A.N. Which comes first: Employee attitudes or organizational financial and market performance? J. Appl. Psychol. 2003, 88, 836-851. [CrossRef]

62. Yoo, J.M.; Choi, W.; Chon, M.L. Do Employees Matter in the Relationship between Corporate Social Responsibility and Financial Performance? Sustainability 2019, 11, 6251. [CrossRef]

63. Porter, M.; Kramer, M. Estrategia y sociedad. Harv. Bus. Rev. 2006, 84, 42-56.

64. Gubler, T.; Larkin, I.; Pierce, L. Motivational Spillovers from Awards: Crowding Out in a Multitasking Environment. Organ. Sci. 2016, 27, 286-303. [CrossRef]

65. Flammer, C.; Luo, J. Corporate social responsibility as an employee governance tool: Evidence from a quasi-experiment. Strat. Manag. J. 2017, 38, 163-183. [CrossRef] 
66. Bode, C.; Singh, J.; Rogan, M. Deep Dive and Back: Social Impact Projects and Employee Retention. Acad. Manag. Proc. 2014, 2014, 15437. [CrossRef]

67. Carnahan, S.; Kryscynski, D.; Olson, D. When does corporate social responsibility reduce employee turnover? Evidence from attorneys before and after 9/11. Acad. Manag. J. 2017, 60, 1932-1962. [CrossRef]

68. Lee, E.M.; Park, S.-Y.; Lee, H.J. Employee perception of CSR activities: Its antecedents and consequences. J. Bus. Res. 2013, 66, 1716-1724. [CrossRef]

69. Clarkson, M.B.E. A stakeholder framework for analyzing and evaluating corporate social performance. Acad. Manag. Rev. 1995, 20, 92-117. [CrossRef]

70. Hristov, I.; Chirico, A.; Appolloni, A. Sustainability Value Creation, Survival, and Growth of the Company: A Critical Perspective in the Sustainability Balanced Scorecard (SBSC). Sustainability 2019, 11, 2119. [CrossRef]

71. Banker, R.D.; Konstans, C.; Mashruwala, R. A Contextual Study of Links between Employee Satisfaction, Employee Turnover, Customer Satisfaction and Financial Performance; The University of Texas at Dallas: Dallas, TX, USA, 2000.

72. Harte, G.; Owen, D. Environmental Disclosure in the Annual Reports of British Companies: A Research Note. Account. Audit. Account. J. 1991, 4, 51-61. [CrossRef]

73. Line, M.; Hawley, H.; Krut, R. The development of global environmental and social reporting. Corp. Environ. Strategy 2002, 9, 69-78. [CrossRef]

74. Jenkins, H.; Yakovleva, N. Corporate social responsibility in the mining industry: Exploring trends in social and environmental disclosure. J. Clean. Prod. 2006, 14, 271-284. [CrossRef]

75. Cornell, B.; Shapiro, A.C. Corporate Stakeholders and Corporate Finance. Financ. Manag. 1987, 16, 5-14. [CrossRef]

76. Memon, M.A.; Salleh, R.; Baharom, M.N.R.; Harun, H. Person-organization fit and turnover intention: The mediating role of employee engagement. Glob. Bus. Manag. Res. 2014, 6, 205-209.

77. Ruf, B.M.; Muralidhar, K.; Brown, R.M.; Janney, J.J.; Paul, K. An Empirical Investigation of the Relationship between Change in Corporate Social Performance and Financial Performance: A Stakeholder Theory Perspective. J. Bus. Ethics 2001, 32, 143-156. [CrossRef]

78. Lin, Y.S.; Jung, C.W. The influence of turnover rate by employee stock bonus. Money Watch. Credit. Rat. 2005, 52, 88-98.

79. Baron, R.M.; Kenny, D.A. The moderator-mediator variable distinction in social psychological research: Conceptual, strategic, and statistical considerations. J. Pers. Soc. Psychol. 1986, 51, 1173-1182. [CrossRef] [PubMed] 